\title{
ESR dating of Middle Pleistocene archaeo-paleontological sites from the Manzanares and Jarama river valleys (Madrid basin, Spain)
}

\author{
Davinia Moreno ${ }^{\mathrm{a}}$,, Mathieu Duval ${ }^{\mathrm{b}}$, Susana Rubio-Jara ${ }^{\mathrm{c}}$, Joaquín Panera ${ }^{\mathrm{a}}$, \\ Jean Jacques Bahain ${ }^{\mathrm{d}}$, Qingfeng Shao ${ }^{\mathrm{e}}$, Alfredo Pérez-González ${ }^{\mathrm{a}}$, Christophe Falguères ${ }^{\mathrm{d}}$ \\ a Centro Nacional de Investigación sobre la Evolución Humana (CENIEH), Paseo Sierra de Atapuerca, 3, 09002, Burgos, Spain \\ ${ }^{\mathrm{b}}$ Australian Research Centre of Human Evolution (ARCHE), Environmental Futures Research Institute (EFRI), Griffith University, 170 Kessels Road, Nathan, \\ QLD 4111, Australia \\ c Instituto de Evolución en África (IDEA), Museo de San Isidro, Plaza de San Andrés, 2, Madrid, Spain \\ d Département de Préhistoire, Muséum National d'Histoire Naturelle, UMR 7194, 1, Rue René Panhard, 75013, Paris, France \\ e College of Geographical Science, Nanjing Normal University, Nanjing, 210023, China
}

\section{A R T I C L E I N F O}

\section{Article history:}

Received 26 April 2017

Received in revised form

21 August 2017

Accepted 8 September 2017

Available online $\mathrm{xxx}$

\section{Keywords:}

Electron Spin Resonance (ESR) dating

Quartz

Ungulate teeth

Fluvial deposits

Manzanares and Jarama valley

Middle Pleistocene

\begin{abstract}
A B S T R A C T
In this work, three important Pleistocene sites of the Madrid basin located close to the junction of the Manzanares (PRERESA site) and the Jarama (Valdocarros site and Maresa quarry) rivers have been studied in order to improve the existing chronological framework of the basin and to clarify the geological evolution of these fluvial systems and their relationship with human occupations. To do so, Electron Spin Resonance (ESR) dating was applied to four fossil teeth and nine optically bleached quartz grain samples. Most of the obtained dates are consistent with the existing preliminary age estimates by biostratigraphy, luminescence (OSL and TL) or Amino Acid Racemization (AAR) dating. This ESR dating study suggests an age of Late Middle Pleistocene (early MIS6) for PRERESA site. At the Jarama valley (Valdocarros site and Maresa quarry), the Arganda I unit could be correlated to the MIS 9 and MIS10, the Arganda II unit seems to belong to MIS8 and MIS7 and the Arganda III to the MIS6.
\end{abstract}

(C) 2017 Elsevier Ltd and INQUA. All rights reserved.

\section{Introduction}

Since the first discovery in 1862 of lithic industry in association with elephant bones at Cerro de San Isidro (Prado, 1864), dozens of archaeo-palaeontological sites have been discovered along the Manzanares and Jarama rivers (Panera and Rubio-Jara, 2002) in the central sector of the Madrid Neogene Basin (Fig. 1a). This high density of preserved sites seems to be related with a synsedimentary subsidence process due to the karstic dissolution of the gypsum in the substratum which favored the accumulation of fluvial sediments and a good conservation of both fauna remains and lithic industry (Pérez-González, 1971, 1980; Rubio-Jara et al., 2002). Establishing a chronological framework for this region is crucial to understand the Quaternary evolution of these fluvial systems as well as to comprehend the rich archaeo-paleontological record located in their fluvial terraces. For a long time, the

\footnotetext{
* Corresponding author.

E-mail address: davinia.moreno@cenieh.es (D. Moreno).
}

chronological data have been derived from micro- and macromammals assemblages (Sesé and Soto, 2000; Sesé et al., 2011a, 2011b) and stone tools technology (Santonja et al., 1980), but the available data base on numerical ages for the central sector of the Madrid basin has significantly increased during the last years. A good compilation of all the available published numerical age-data on the fluvial sequences in the Madrid Basin can be found in Silva et al. (2016) and in Rubio-Jara et al. (2016). Hence, the presentday chronostratigraphic framework of this region for terraces down to $+40 \mathrm{~m}$ above the present channel is based on amino acid racemization (AAR) (Panera et al., 2011), luminescence (TL and OSL) (Pérez-González et al., 2008) paleomagnetism (Pérez-González et al., 2013) and radiocarbon dating (Wolf et al., 2013).

In order to improve and refine the existing chronostratigraphical framework, the Electron Spin Resonance (ESR) dating has been applied to four fossil teeth and nine optically bleached quartz grains samples coming from two archaeological sites and a sand/ gravel quarry located within fluvial deposits from the Manzanares and Jarama river terrace systems (Madrid Basin). 


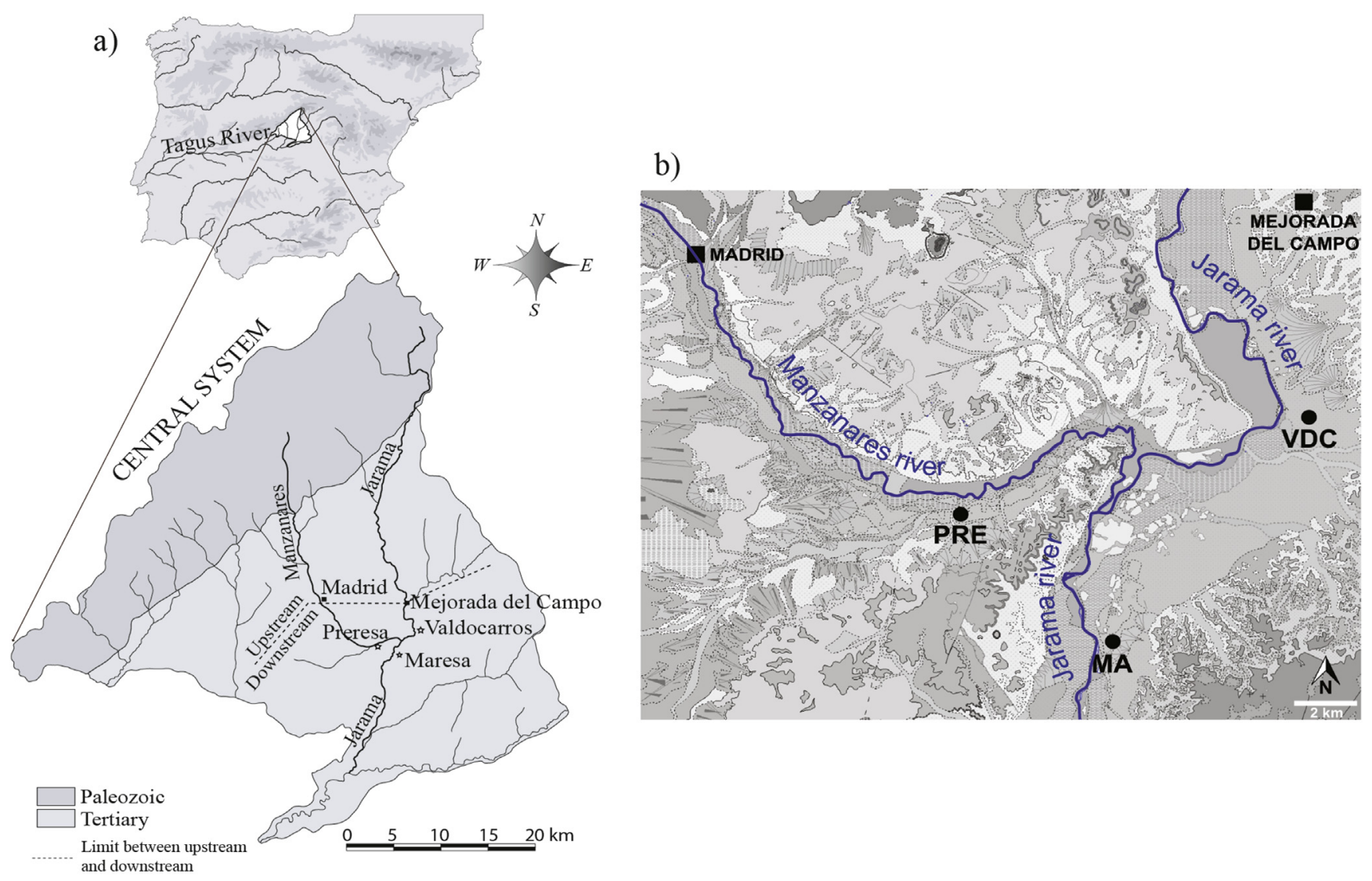

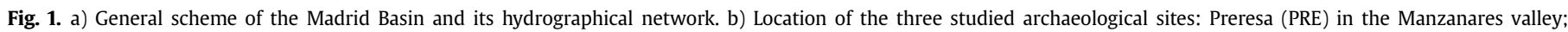

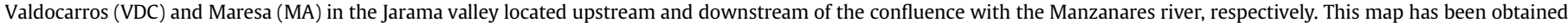
from http://igme.maps.arcgis.com/ where the legend and the complete map of the region can be consulted.

\section{The Madrid Basin}

The Madrid Basin is an intracratonic and triangular basin bounded on its three sides by Tertiary mountain ranges: the Spanish Central system in the north, the Toledo Mountains in the south and the Iberian range in the east (Fig. 1a) (De Vicente et al., 1996). This basin is over $20.000 \mathrm{~km}^{2}$ and was filled by Tertiary sediments between 2000 and 3500 m thick. Due to its strategic location between three mountain ranges which have a different structures and Tertiary geological evolutions, the Madrid Basin shows a complex deformational history as a result of differential compressive strains from the North and South during Alpine movements. Concurrently with this complicated tectonic activity and following the main fault lineages, an important hydrographic network was developed in this area (Silva et al., 1988; Giner et al., 1996) corresponding with the upstream part of the Tagus drainage basin which is composed of several water bodies. The materials that infilled the basin are mainly represented by conglomerates with limestone and quartzite boulders, sandstones, clays marls, limestones and gypsums (De Vicente and MuñozMartín, 2013).

Two of the most important water bodies in the Madrid Basin are the Jarama and Manzanares rivers. Their alluvial terraces systems show a high number of terraces and are rich in palaeontological and archaeological sites. The Quaternary evolution of the Jarama and Manzanares fluvial systems has been controlled by synsedimentary subsidence due to the karstification of the evaporitic bedrock. This phenomenon is a well-known process in the large tertiary continental basins in Spain (Benito et al., 2000). It produces anomalous morphostratigrahical features because alluvial systems counterbalance subsidence by aggradation to maintain a dynamic equilibrium profile of the alluvial surface. The replication of the synsedimentary subsidence through a particular area results in significant thickening of fluvial deposits and superposition of the deposits correlative to different terrace levels (Pérez-González, 1971).

\subsection{Manzanares river valley}

The Manzanares River has its source in the Guadarrama mountain range and flows in the Jarama River $92 \mathrm{~km}$ later. Upstream from the city of Madrid the river follows an N-S direction until the confluence with the Butarque stream where the valley progressively turns into an NW-SE arched direction until joining the Jarama River (Fig. 1b). The upstream reach of the valley exhibits thirteen levels of stepped alluvial terraces (T1-T13) with a maximum relative height of $+95 \mathrm{~m}$ and a minimum relative height of $+4-5 \mathrm{~m}$ above the present thalweg (Pérez-González, 1994) (Table 1). These alluvial deposits are 3-4 m thick and consist of sands and gravels overlain by floodplain fine-grained deposits with well-developed soils (Goy et al., 1989). The lower reach of the valley is carved in evaporitic bedrock and is affected by synsedimentary subsidence which normally displays thickened fluvial sequences and creates a system of overlapped (complex) terraces. The socalled Complex Terrace of Butarque (hereafter CTB) by Goy et al. (1989), also called Complex Terrace of Manzanares (TCMZ) (Silva, 2003), is the most extensive terrace level developed in the lower reach of the valley and it could be composed of at least two terraces, 
namely T9 (+18-20 m) and T8 (+25-30 m) (Pérez-González and Uribelarrea, 2002). Since the mid-20th, many palaeontological and/or archaeological sites have been identified and excavated within the deposits associated to the CTB terrace (Panera and Rubio-Jara, 2002), which is contrasting with fluvial terraces located higher than $+40 \mathrm{~m}$ above the present thalweg where bone remains and lithic artefacts are mostly absent (Rubio-Jara et al., 2016).

The chronology of the terrace sequence at the Manzanares river valley has been traditionally derived from regional relative height correlations, bio- and archaeo-stratigraphy (Table 1). In this way, the fluvial levels between T12 and T9 $(+8 \mathrm{~m}$ and $+20 \mathrm{~m})$ have been tentatively ascribed to the Upper Pleistocene, while terraces between T9 and T4 $(+20 \mathrm{~m}$ and $+60 \mathrm{~m})$ to the Middle Pleistocene and those higher than $+60 \mathrm{~m}$ (T4 - T1) to the Lower Pleistocene (PérezGonzález and Uribelarrea, 2002; Rubio-Jara et al., 2016). The CTB has traditionally been ascribed to the Middle Pleistocene, which is corroborated by the abundant remains of large mammals such us Elephas (Palaeoloxodon) antiquus, Dicerorhinus hemitoechus, Bos primigenius, Equus caballus, Cervus elaphus (Sesé and Soto, 2000) and the Acheulean industry found at the bottom of the terrace (Rubio-Jara et al., 2016). However, the available numerical dates, taken from different sites spread along the CTB, indicate that the T9 $(+18-20 \mathrm{~m})$ level may include the Middle-Late Pleistocene boundary (Pérez-González et al., 2008; Silva et al., 2008, 2012; Domínguez-Alonso et al., 2009; Laplana et al., 2015). In the Arriaga sand quarry, also located within the CTB, two thermoluminescence (TL) dates provided minimum ages of $133 \mathrm{ka}$ and 134 ka (Silva et al., 2011, 2012) and may position the lower outcrop of the CTB within the final part of the Middle Pleistocene (Sesé and López-Martínez, 2013). At EDAR Culebro 1 site, an OSL date of $121 \pm 7 \mathrm{ka}$ and two AAR dates on an Equus sp. molar (133 \pm 28 and $105 \pm 10 \mathrm{ka}$ ) have been obtained (Manzano et al., 2010). At Los Estragales site, the lower alluvial sequence has provided one Optically Stimulated Luminescence (OSL: $107+39 /-22 \mathrm{ka}$ ) and one Termoluminescence (TL: $122 \pm 11 \mathrm{ka}$ ) ages for the bottom of the CTB. Another OSL date for the top of the sequence, $91 \pm 9 \mathrm{ka}$ (PérezGonzález et al., 2008) was calculated. The site of PRERESA has been dated to $84 \pm 5.6$ ka by OSL on feldspar grains (Yravedra et al., 2012; Panera et al., 2014). The T10 $(+12-15 \mathrm{~m})$ level has also provided two TL ages: $40 \pm 3 \mathrm{ka}$ (Pérez-González et al., 2008) and $40 \pm 5 \mathrm{ka}$ at the E.T.B site (Domínguez-Alonso et al., 2009).

\subsection{Jarama river valley}

The Jarama River has its source in the Sierra de Guadarrama and after $150 \mathrm{~km}$ crossing the Madrid Basin southwards, flows into the Tagus River. This is an asymmetric valley which exhibits gypsum cliffs along the right bank and a sequence of alluvial terraces on the left bank. Downstream of Mejorada del Campo and upstream of Arganda del Rey, a sequence of fifteen stepped alluvial terraces (T1T15) with a maximum of $+140-145 \mathrm{~m}$ and a minimum of $+4-5 \mathrm{~m}$ relative height (Pérez-González, 1994) above the present thalweg (Table 1). In this area, only the alluvial terraces higher than $+40 \mathrm{~m}$ are stepped. The lower terraces are affected by synsedimentary subsidence processes resulting to the Complex Terrace of Arganda (hereafter CTA). The CTA is composed of four alluvial sequences called Arganda I, II, III and IV (from the bottom to the top) that can reach up to 40-50 $\mathrm{m}$ in thickness (Pérez-González, 1971, 1980; 1994) (Fig. 2). Arganda I (T12: $+30-32 \mathrm{~m}$ ) is characterized by a succession of sandy levels locally cut by thin gravel beds and all overlained by foodplain silt-clay deposits while Arganda II (T13: $+23-24 \mathrm{~m}$ ) is composed by a series of gravel bars. Arganda III (T14: $+18-20 \mathrm{~m}$ ) is a new alluvial terrace, enclosed $\sim 5 \mathrm{~m}$ in Arganda II and composed of gravel bars cemented by calcium carbonate. Arganda IV is constituted by slope deposits coming from the nearby Miocene and Quaternary reliefs (Pérez-González, 1980). On the CTA deposits, numerous palaeontological and archaeological sites have been discovered such as Áridos 1 and 2, HAT, Valdocarros and Maresa (Santonja et al., 1980; Panera et al., 2005; Panera, 2009; Rubio-Jara et al., 2016).

The chronology of the terrace sequence at the Jarama river valley has been established on the combination of regional relative height correlations, biostratigraphy, numerical dating and palaeomagnetism (Table 1). The CTA numerical time frame has been established by a combination of biostratigraphy (López-Martínez, 1980; Sesé et al., 2011a,b) with amino-acid racemization (AAR) dating (Panera et al., 2011). In Arganda I and Arganda II, the micromammals associations from Áridos 1 and Valdocarros, respectively, suggest a late Middle Pleistocene age for these deposits. The AAR results indicate that the Arganda I unit $(332 \pm 38$ and $379 \pm 45 \mathrm{ka}$ at Maresa site) spans the last part of MIS 11 or early MIS 9, which is coherent with the micromammals association. The Arganda II unit at Valdocarros site yielded three ages. Two of them $(254 \pm 47$ and $262 \pm 07 \mathrm{ka})$ are internally consistent and in agreement with the biostratigraphy and may correspond with an interstadial within the cold stage MIS 8 or the MIS 8/7 transition (Blain et al., 2012). The third date $(174 \pm 20 \mathrm{ka})$ is however, significantly younger and does not overlap with the other two (Panera et al., 2011). Because of the hardening of sediments in Arganda III unit no micromammal remains have been found and no numerical dates have been obtained. In Arganda IV several numerical ages obtained by TL $(112+36 /-22 \mathrm{ka}$ and $85+18-13 \mathrm{ka}$ at Torreblanca; $74+16-12 \mathrm{ka}$ at HAT) and OSL ( $80 \pm 7 \mathrm{ka}$ at Valdocarros and $74 \pm 5 \mathrm{ka}$ at Maresa) suggest an Upper Pleistocene age for this unit, which may correlate with MIS 5 (Panera et al., 2011). The Brunhes-Matuyama boundary $(0.780 \mathrm{Ma})$ has been recorded between the terrace T8 $(+60-65 \mathrm{~m}$; reverse polarity) and the T9 (+55-60 m; normal polarity) (Pérez-González et al., 2013). This is consistent with the results obtained on Arlanzón river valley (Duero basin) which show an Electron Spin Resonance (ESR) date of at least $780 \mathrm{ka}$ and reverse polarity for T4 $(+60-67 \mathrm{~m})$ and an ESR age of $670 \mathrm{ka}$ and normal polarity for T5 ( $+50-54 \mathrm{~m}$ ) (Benito-Calvo et al., 2008; Moreno et al., 2012).

\section{The archaeological sites studied}

The sites studied in this paper are PRERESA in the Manzanares valley and Valdocarros and Maresa in the Jarama valley located upstream and downstream of the confluence with the Manzanares River, respectively (Fig. 1b).

\subsection{PRERESA (PRE) site}

The PRERESA site was discovered in 2003, $5.5 \mathrm{~m}$ below the top of the CTB, thanks to archaeological surveys (Panera et al., 2009). The stratigraphy of the site includes, from the bottom to the top, sandy bars and channel fills floodplain sediments followed by sandy bars with gravels showing crossed-stratigraphy topped by a sequence of clays and muds (Fig. 31). An area of $255 \mathrm{~m}^{2}$ was excavated in a $30 \mathrm{~cm}$-thick greenish clayey facies. 754 lithic pieces were recorded, all made of flint apart from six pieces of quartz. The lack of macrotools and the low occurrence of retouched tools are remarkable. Among these, the most common are retouched flakes, denticulates and compound tools. A scraper and a burin were also recorded. The presence of knapping remains demonstrates that these flakes were shaped in situ (Rubio-Jara, 2011). Lithic remains are associated with an important association of macromammals such as Haploidoceros mediterraneus, Vulpes vulpes, Lynx pardinus, Meles meles, Canis lupus, Proboscidea indet., Equus sp., Cervus elaphus, Dama sp., Capreolus 
Table 1

Terrace sequences of the Manzanares and Jarama valleys displaying the maximum number of terrace levels recorded in the work area with indication of the relative height in m, above the present thalweg (FP: floodplain) (PérezGonzález, 1994; Rubio-Jara et al. 2016) along with palaeomagnetic, paleontological data and numerical ages: TL (Thermoluminescence), OSL (Optically Stimulated Luminescence) and AAR (Amino Acid Racemisation) (PérezGonzález et al., 2008; Domínguez-Alonso et al., 2009; Manzano et al., 2010; Panera et al., 2011, 2014; Silva et al., 2012; Yravedra et al., 2012).

\begin{tabular}{|c|c|c|c|c|c|c|c|c|c|c|c|c|c|c|c|}
\hline & & \multicolumn{8}{|c|}{ Manzanares valley } & \multicolumn{5}{|c|}{ Jarama valley } & \multirow[t]{4}{*}{ Techno- Complex } \\
\hline & & \multicolumn{2}{|c|}{ Terraces $(\mathrm{m})$} & \multicolumn{6}{|c|}{ Numerical ages (ka) } & \multicolumn{2}{|c|}{ Terraces $(\mathrm{m})$} & \multicolumn{2}{|c|}{ Numerical ages $(\mathrm{ka})$} & \multirow[t]{3}{*}{ Magnetostratigraphy } & \\
\hline & & & & \multirow{2}{*}{$\frac{\text { Arriaga }}{\mathrm{TL}}$} & \multicolumn{2}{|c|}{ Edar Culebro } & \multirow{2}{*}{$\begin{array}{l}\text { Estragales } \\
\mathrm{OSL} / \mathrm{TL}\end{array}$} & \multirow{2}{*}{$\frac{\text { E.T.B. }}{\mathrm{TL}}$} & \multirow{2}{*}{$\frac{\text { PRERESA }}{\text { OSL }}$} & & & \multirow{2}{*}{$\frac{\text { Valdocarros }}{\text { AAR }}$} & \multirow{2}{*}{$\frac{\text { Maresa }}{\text { AAR }}$} & & \\
\hline & & & & & $\mathrm{TL}$ & AAR & & & & & & & & & \\
\hline \multirow[t]{2}{*}{ Holocene } & & FP & $+1-1,5$ & & & & & & & & & & & & \\
\hline & & $\mathrm{T} 13$ & $+4-5$ & & & & & & & T15 & $+4-5$ & & & & \\
\hline \multirow[t]{22}{*}{ Pleistocene } & Upper Pleistocene & $\mathrm{T} 12$ & +8 & & & & & & & & & & & & \\
\hline & & $\mathrm{T} 11$ & +10 & & & & & & & & & & & & \\
\hline & & $\mathrm{T} 10$ & $+12-15$ & & & & & $\begin{array}{l}40 \pm 5 \\
40 \pm 3\end{array}$ & & & & & & & \\
\hline & & T9 & $+18-20$ & $>133$ & $121 \pm 7$ & $105 \pm 10$ & $122 \pm 11$ & & $84 \pm 5.6$ & T14 & $+18-20$ & & & & Middle Paleolithic Acheulean \\
\hline & & & $\approx \mathrm{CTB}$ & $134 \pm 50$ & & $133 \pm 28$ & $\begin{array}{l}107+39 /-22 \\
91 \pm 9\end{array}$ & & & & $\approx$ Arganda III CTA & & & & \\
\hline & Middle Pleistocene & T8 & $+25-30$ & & & & & & & T13 & $+23-24$ & $254 \pm 47$ & & & Acheulean \\
\hline & & & $\approx \mathrm{CTB} ?$ & & & & & & & & $\approx$ Arganda II & $262 \pm 07$ & & & \\
\hline & & & & & & & & & & & CTA & $174 \pm 20$ & & & \\
\hline & & $\mathrm{T} 7$ & $+35-40$ & & & & & & & T12 & $+30-32$ & & $332 \pm 38$ & & \\
\hline & & & & & & & & & & & $\approx$ Arganda I CTA & & $379 \pm 45$ & & \\
\hline & & & & & & & & & & T11 & $+40-41$ & & & & \\
\hline & & T6 & $+44-46$ & & & & & & & & & & & & \\
\hline & & T5 & $+52-54$ & & & & & & & T10 & $+52-53$ & & & & Acheulean? \\
\hline & & & & & & & & & & T9 & $+55-60$ & & & Normal polarity & \\
\hline & Lower Pleistocene & $\mathrm{T} 4$ & +60 & & & & & & & T8 & $+60-65$ & & & Reverse polarity & \\
\hline & & T3 & $+68-72$ & & & & & & & $\mathrm{~T} 7$ & +74 & & & & Indeterminate \\
\hline & & $\mathrm{T} 2$ & $+80-85$ & & & & & & & T6 & $+84-86$ & & & & \\
\hline & & $\mathrm{T} 1$ & +95 & & & & & & & T5 & +92 & & & & \\
\hline & & & & & & & & & & $\mathrm{T} 4$ & $+100-104$ & & & & \\
\hline & & & & & & & & & & T3 & $+110-114$ & & & & \\
\hline & & & & & & & & & & T2 & $+125-130$ & & & & \\
\hline & & & & & & & & & & $\mathrm{T} 1$ & $+140-145$ & & & & \\
\hline
\end{tabular}



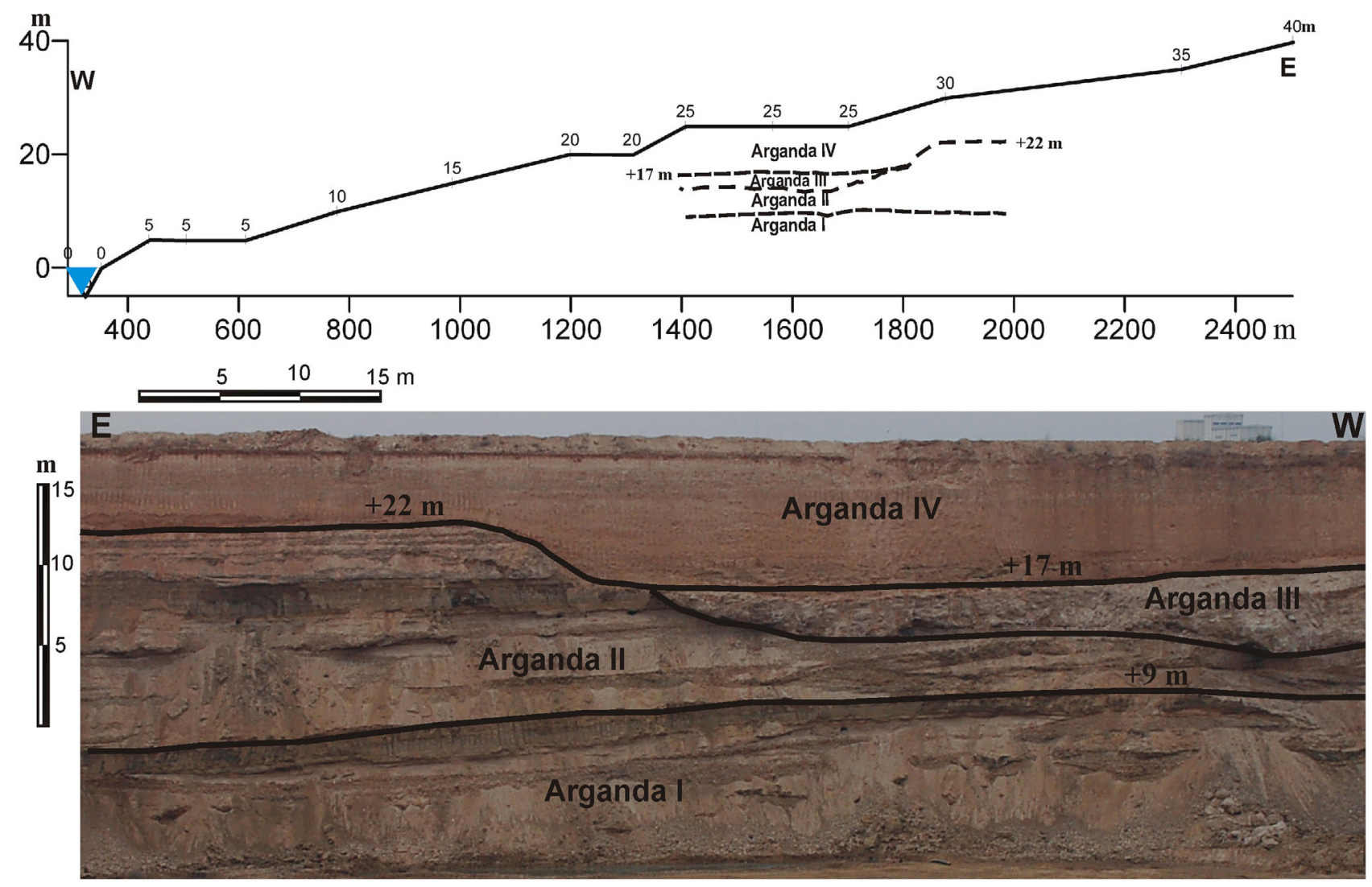

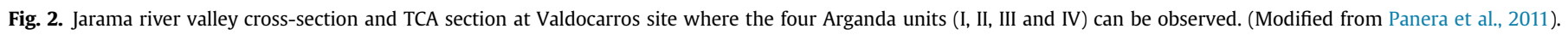

capreolus and Bos primigenius (Panera et al., 2014) in addition to micromammal and herpetofauna remains. The small-mammal assemblage mainly includes Erinaceomorpha: Erinaceus europaeus; Soricomorpha: Crocidura russula; Chiroptera: Rhinolophus ferrumequinum; Rodentia: Eliomys quercinus, Apodemus sp., Cricetulus (Allocricetus) bursae, Arvicola aff. sapidus, Microtus cabrerae, Microtus duodecimcostatus; Lagomorpha: Oryctolagus cuniculus (Sesé et al., 2011a). The herpetological assemblage consists of Pelobates cultripes, Pelodytes, sp., Bufo bufo, Bufo calamita, Hyla sp., Pelophylax perezi, Natri maura, Vipera tatastei (Blain et al., 2013). According to the presence of Microtus cabrerae and an OSL age $(84 \pm 5.6 \mathrm{ka})$, that we will discuss below, the site has been assigned to MIS5.

\subsection{Valdocarros $(V D C)$ site}

Valdocarros is an open-air site located within the CTA in the Jarama valley where the four Arganda units have been recorded. In Arganda I and II units important concentrations of faunal remains and stone tools has been discovered while in the Arganda III there are no remains (Fig. 3). The archaeological excavation was focused in the upper part of the Arganda II (Rubio-Jara et al., 2016). About $840 \mathrm{~m}^{2}$ were excavated in 2005 delivering a faunal assemblage of $\sim 2750$ bones composed by Cervus elaphus, Equus caballus, Dama, sp., Elephas sp., Bos primigenius, Capreolus sp., Felix sp., Canis lupus and Vulpes vulpes. Bones are very fragmented due to both anthropogenic as well as to fossil diagenetic processes (Yravedra and Domínguez-Rodrigo, 2008). The micrommamal assemblage includes Erinaceomorpha: Erinaceus europaeus; Soricomorpha: Crocidura russula; Rodentia: Eliomys quercinus, Castor fiber, Apodemus sp., Cricetulus (Allocricetus) bursae, Arvicola aff. sapidus, Microtus brecciensis and Lagomorpha: Oryctolagus cuniculus (Sesé et al., 2011b). This places the site of Valdocarros in the Middle Pleistocene, especially by the presence of Microtus brecciensis, one of the most characteristics species of this period. The Palaeolithic industry ( 3000 stone tools) includes activity of knapping, façonnage of handaxes and cores. These stone stools may be ascribed to the Acheulean techno-complex (Panera, 2009; Rubio-Jara et al., 2016).

\subsection{Maresa (MA) quarry}

Maresa is a quarry located within the CTA in the Jarama valley where the four Arganda units have also been recorded (Fig. 3). In all of these units, important concentrations of palaeolithic stone tools have been found in secondary position which may be ascribed to the Acheulean techno-complex by correlation with other sites of the region. In the Arganda I unit, an excavation of about $8 \mathrm{~m}^{2}$, delivered a partial cervid postcranial skeleton but no micromammal remains or lithic industry associated (Panera, 2009). Palynological analyses suggest the prevailing presence of open landscapes (Ruíz-Zapata et al., 2006). According with two AAR ages $(332 \pm 38 \mathrm{ka}$ and $379 \pm 45 \mathrm{ka})$, this site could be assigned to Middle Pleistocene.

\section{Material and methods}

\subsection{Sampling}

A total of 13 samples ( 9 samples of sediment and 4 teeth) were collected during three different fieldworks in 2005, 2007 and 2012. 
Manzanares valley

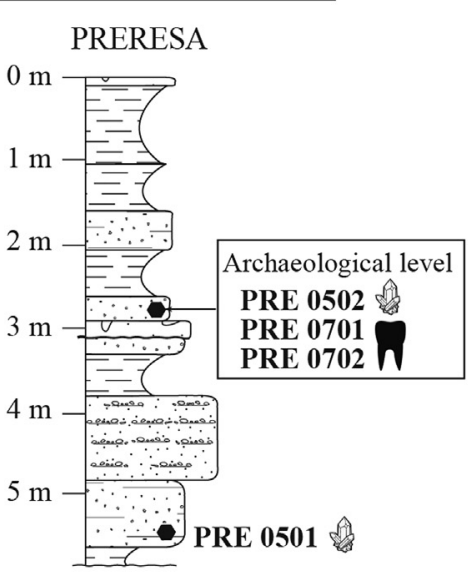

Jarama Valley
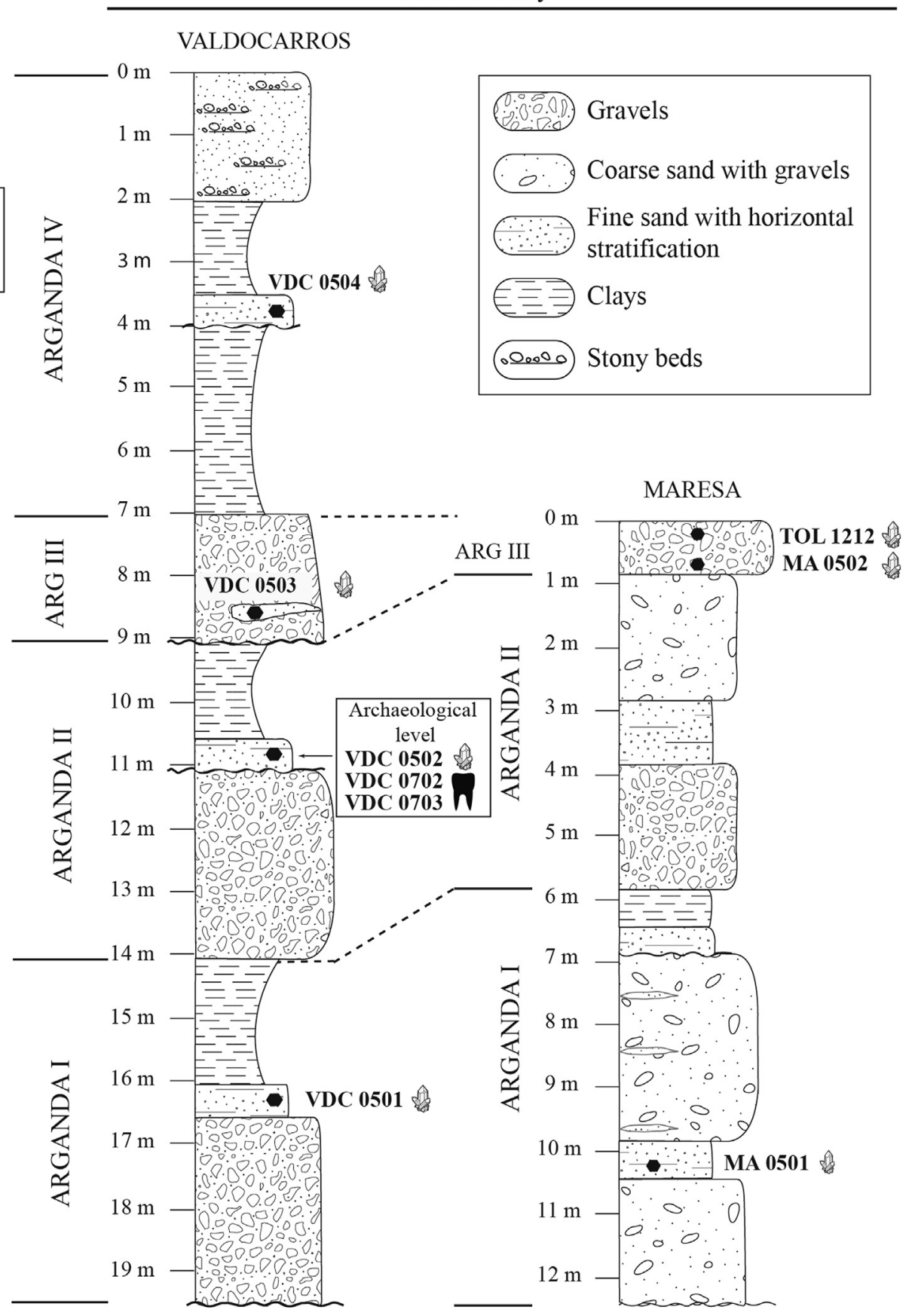

Fig. 3. Local stratigraphy of the sampled sites and position of the ESR samples of quartz and teeth $n$.

Eight samples of sediment were taken during a fieldwork campaign along the Jarama and Manzanares valleys in 2005 (Figs. 3 and 4). At the Manzanares valley, two samples were collected from the PRERESA site (PRE0501 and PRE0502) which were located about $3 \mathrm{~m}$ and $30 \mathrm{~cm}$ below the archaeological level, respectively. At the Jarama valley, one sample was collected for each of the Arganda units identified at the Valdocarros site: VDC0501 (Arganda I unit), VDC0502 (Arganda II unit), VDC0503 (Arganda III unit) and VDC0504 (Arganda IV unit). The sample VDC0502 was taken in the archaeological level, whereas VDC0501 was located $5 \mathrm{~m}$ below, and VDC0503 and VDC0504 3 and $8 \mathrm{~m}$ above the archaeological level, respectively. At the Maresa quarry, two samples were collected:
MA0501 (Arganda I) and MA0502 (Arganda III) respectively $3 \mathrm{~m}$ below and $6 \mathrm{~m}$ above the archaeological level. At each site, sediment samples were collected from freshly cleaned sections, specifically from sandy levels.

A second fieldwork campaign was carried out in 2007 along the Manzanares and Jarama valleys and four teeth from large mammal were sampled for ESR/U-series analyses. At the Manzanares valley, two teeth were collected from the archaeological level at PRERESA site (PRE0701 and PRE0702). In the Jarama valley, two other teeth were also collected from the archaeological level at Valdocarros site (VDC0702 and VDC0703). In situ gamma spectrometry was performed using a NaI probe connected to an Inspector1000 


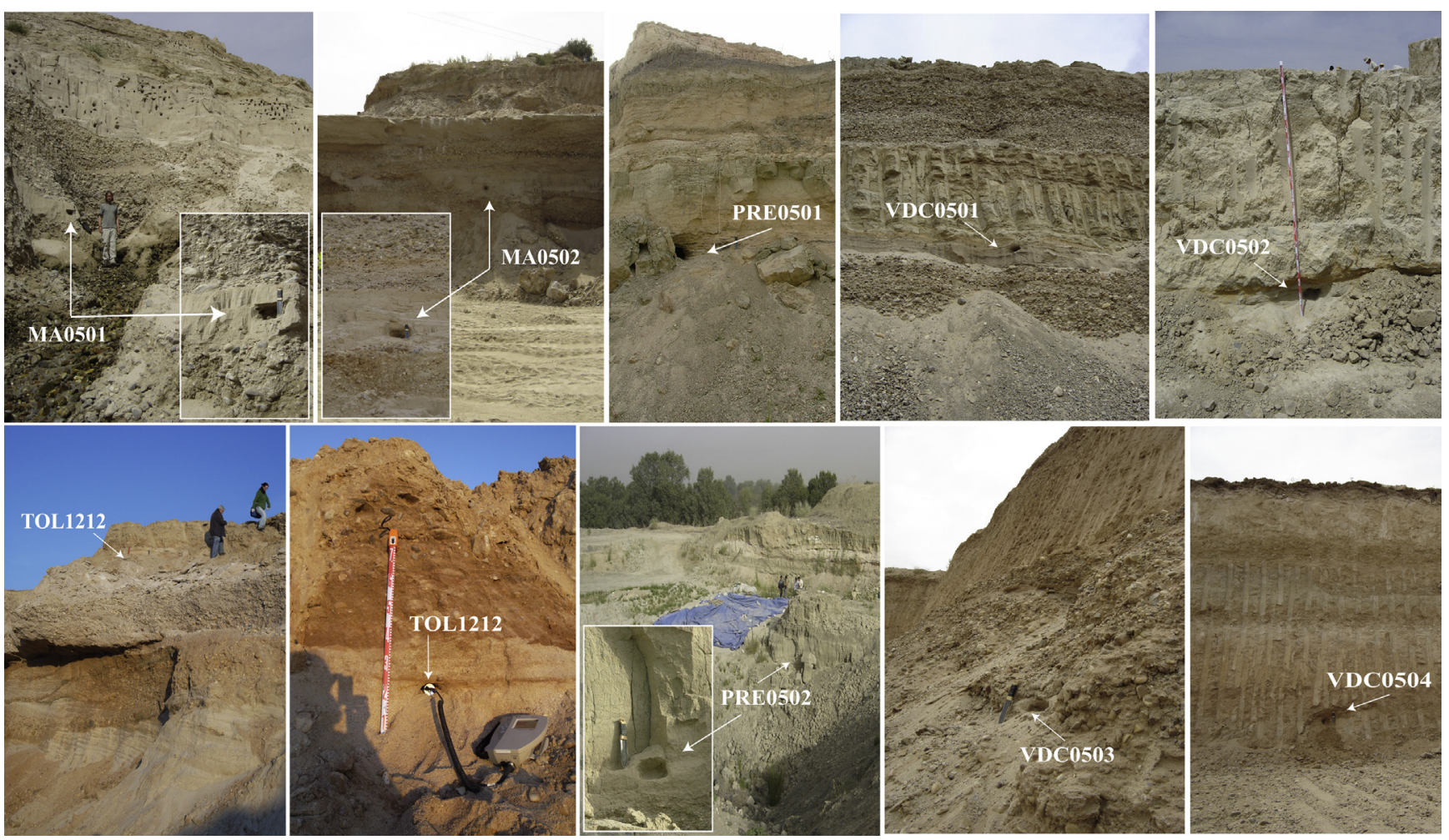

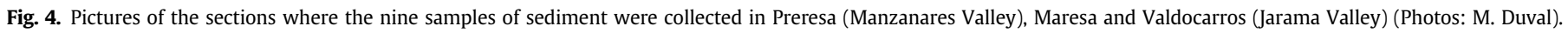

multichannel analyzer (Canberra) and inserted directly into the archaeological layers.

Finally, a third fieldwork campaign occurred in 2012 along the Jarama and Tagus valley and a last sediment sample (TOL1212) was taken in the Arganda III unit at the Maresa quarry. In situ gamma spectrometry was performed directly at the exact sampling spot using the same device as previously.

\subsection{ESR dating of quartz grains}

\subsubsection{Sample preparation}

Sample preparation was carried out at the Muséum national d'Histoire naturelle (MNHN) (Paris, France) and at the Centro Nacional de Investigación sobre la Evolución Humana (CENIEH) (Burgos, Spain). Sediments were prepared following the standard procedure described in Voinchet et al. (2007) in order to extract pure quartz grains between 100 and $200 \mu \mathrm{m}$. The Multiple Aliquots Additive (MAA) dose approach for dating quartz grains was applied. Each sample was divided into 12 multiple grain aliquots. Ten of these aliquots were irradiated using a panoramic ${ }^{60} \mathrm{Co} \gamma$-ray source (Dolo et al., 1996) at doses ranging from 400 to $25.000 \mathrm{~Gy}$ following a subexponential dose step distribution. During the irradiation, several alanine dosimeters were positioned between the quartz aliquots to monitor the dose effectively received by the samples. For each sample, one aliquot was preserved (natural) and one aliquot was optically bleached for $\sim 1500$ h using a SOL2 (Dr. Hönle) solar light simulator in order to evaluate the ESR intensity of the nonbleachable residual signal associated to the Aluminium center of quartz (Voinchet et al., 2003).

\subsubsection{ESR dose reconstruction}

ESR measurements were performed at low temperature ( $90-100 \mathrm{~K})$ using a nitrogen gas flow system connected to a EMX Bruker X-band ESR spectrometer at the Muséum national d'Histoire naturelle (Paris, France) and an EMXmicro 6/1 Bruker X-band ESR spectrometer at the Centro Nacional de Investigación sobre la Evolución Humana (CENIEH) (Burgos, Spain). The following experimental conditions were employed for the Al center: $5 \mathrm{~mW}$ microwave power, 1024 points resolution, $100 \mathrm{kHz}$ modulation frequency, $1 \mathrm{G}$ modulation amplitude, $40 \mathrm{~ms}$ conversion time, $40 \mathrm{~ms}$ time constant, $9 \mathrm{mT}$ sweep width and 1 scan. The ESR signal associated to the Ti center was measured as follows: $5 \mathrm{~mW} \mathrm{mi-}$ crowave power, 1024 points resolution, $100 \mathrm{kHz}$ modulation frequency, $1 \mathrm{G}$ modulation amplitude, $60 \mathrm{~ms}$ conversion time, $40 \mathrm{~ms}$ time constant, $200 \mathrm{G}$ sweep width and 1-3 scan. The angular dependence of the ESR signal due to sample heterogeneity was taken into account by measuring each of the twelve aliquots (one natural, one optically bleached and ten $\gamma$-irradiated) of a given sample three times after a $\sim 120^{\circ}$ rotation in the cavity. Furthermore, data reproducibility was checked by running ESR measurements over different days. This procedure was carried out for both the $\mathrm{Al}$ and Ti signals.

The ESR intensity of $\mathrm{Al}$ center was extracted from peak-to-peak amplitude measurements between the top of the first peak $(\mathrm{g}=2.0185)$ and the bottom of the 16th peak $(\mathrm{g}=2.002)$ of the $\mathrm{Al}$ hyperfine structure (Toyoda and Falguères, 2003). The ESR intensity of the Ti centers was measured in four different ways following the conclusions from Duval and Guilarte (2015) (Fig. 5):

- Peak-to-peak amplitude measurement between $\mathrm{g}=1.979$ and the bottom of the peak at $\mathrm{g}=1.913$ (option A; Ti-Li center)

- Peak-to-baseline amplitude measurement around $\mathrm{g}=1.913-1.915$ (option D; Ti-Li center)

- Peak-to-baseline amplitude measurement at $\mathrm{g}=1.979$ (Option E; Ti-Li center)

- Peak-to-baseline amplitude measurement around $\mathrm{g}=1.915$

(Option C; Ti-H center). 

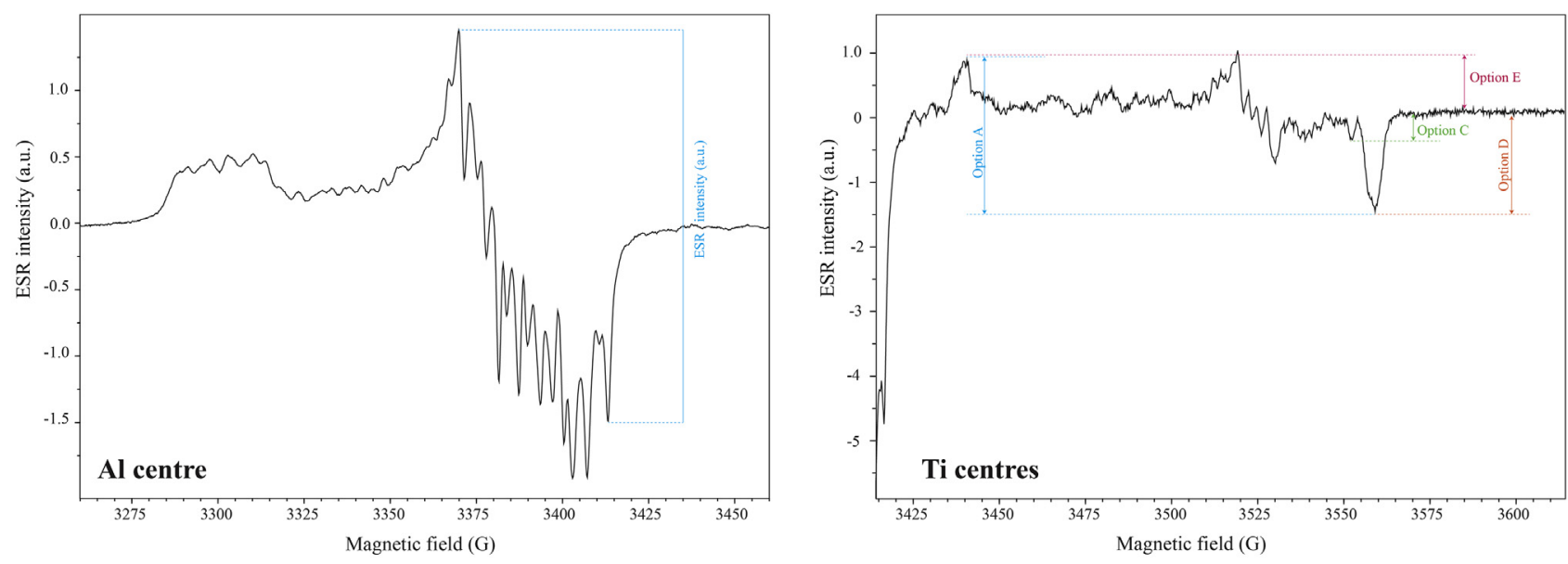

Fig. 5. ESR spectra associated with the Al centre (left) and with the Ti centres (right) measured on a natural aliquot of quartz from Maresa site (TOL1212).

For each aliquot, ESR intensities of $\mathrm{Al}$ and Ti centers were corrected by the corresponding receiver gain value, number of scans and aliquot mass. Final ESR intensities correspond to the mean value derived from the repeated measurements.

The equivalent dose $\left(D_{E}\right)$ values were calculated with the Microcal Origin 8.5 software using the Levenberg-Marquardt algorithm by chi-square minimization. For the Al center, a single saturating exponential + linear function (SSE+LIN) (Duval et al., 2009) was fitted through the experimental points. For the Ti centers, two fitting functions were tested (Duval and Guilarte, 2015): the Ti-2 function initially proposed by Woda and Wagner (2007) and the single saturating exponential function (SSE). With the SSE and SSE+LIN functions, data were weighted by the inverse of the squared ESR intensity $\left(1 / \mathrm{I}^{2}\right)$, whereas equal weights were used with the function Ti-2, as described in Duval et al. (2015) (Fig. 6).

\subsubsection{Dose rate evaluation and age calculation}

The dose rate is derived from the analysis of radioactive elements in the sample and its surroundings.

$\sim 5 \mathrm{~g}$ of prepared quartz grains were analyzed by ICP-MS analysis in order to obtain the radioelement concentrations ( $\mathrm{U}, \mathrm{Th}, \mathrm{K}$ ) for the evaluation of the internal dose rate. In addition, $\sim 100 \mathrm{~g}$ of raw sediment from all samples were also analyzed by high resolution $\gamma$ spectrometry (HRGS) in order to derive $\alpha, \beta$ and $\gamma$ external dose rate values (Table 2). For PRE0502 sample, external $\gamma$ dose rate derived from in situ measurements was also available.

Total dose rates were calculated using the dose rate conversion factors from Adamiec and Aitken (1998). Values were corrected with $\beta$ and $\alpha$ attenuations for spherical grains (Brennan et al., 1991; Brennan, 2003) and water attenuation formulae from Grün (1994). A water content of $10 \%$ was assumed for all samples. A $\alpha$-efficiency k-value of $0.15 \pm 0.10$ (Yokoyama et al., 1985) was assumed for the alpha dose rate. The cosmic dose rate was calculated from the equations of Prescott and Hutton (1994), with latitude, altitude and depth corrections.

ESR age calculation was performed using a non-commercial software based on DRAC (Durcan et al., 2015) which takes into account the uncertainties derived from concentrations, depth, water content, in situ gamma dose rate, attenuations and $D_{E}$ values. The errors associated with total doses, equivalent doses and ESR age results are given at $1 \sigma$.

\subsection{ESR/U-series dating of teeth}

Teeth from PRERESA and Valdocarros archaeological levels were analyzed according to the combined ESR/U-series method (Grün et al., 1988).

\subsubsection{Sample preparation}

Teeth were prepared following the protocol detailed by Bahain et al. (2012) at the MNHN (Paris, France). A part of external enamel layer was extracted from each tooth which was then cleaned on each side in order to avoid any contamination by sediment, cement or dentine. After grounding and sieving, the $100-200 \mu \mathrm{m}$ grain-size fraction of the obtained clean enamel was split into 14 aliquots. Thirteen of them were irradiated using ${ }^{60} \mathrm{Co}$
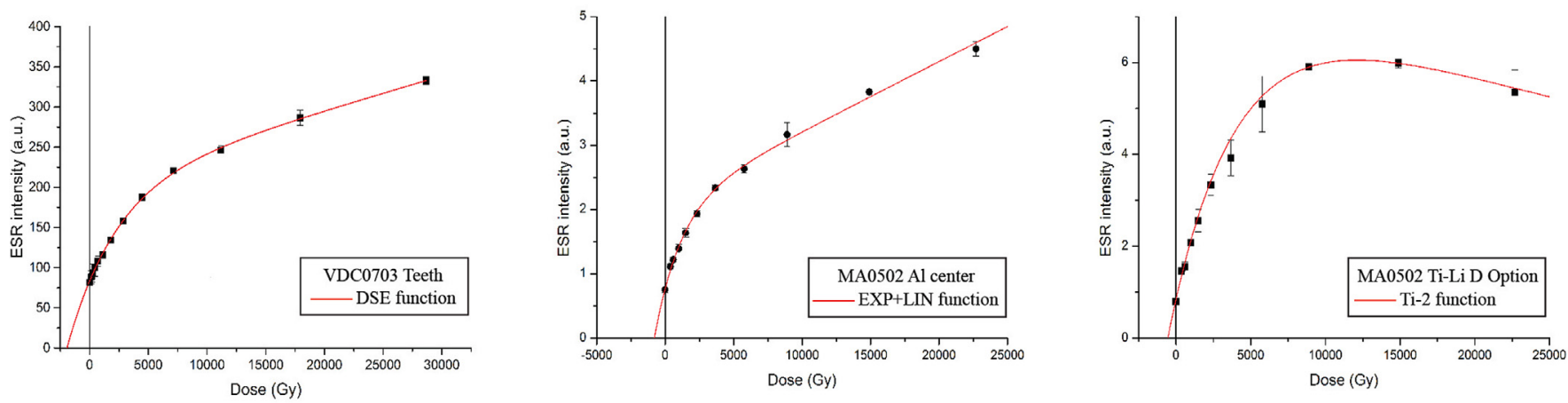

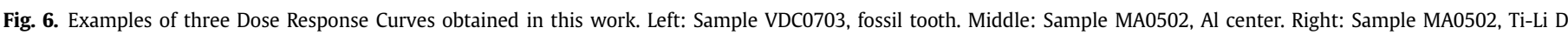
option. 
Radioelement concentration values obtained by ICP and high resolution $\gamma$ spectrometry (HRGS) from powder of raw material and prepared quartz grains.

\begin{tabular}{|c|c|c|c|c|c|c|c|c|c|c|c|}
\hline & & & \multicolumn{3}{|c|}{ Prepared quartz grains } & \multicolumn{6}{|c|}{ Powder of raw sediment } \\
\hline & & & \multicolumn{3}{|l|}{ ICP } & \multicolumn{3}{|l|}{ HRGS } & \multicolumn{3}{|l|}{$\underline{\text { ICP }}$} \\
\hline & & & ${ }^{238} \mathrm{U}(\mathrm{ppm})$ & ${ }^{232} \mathrm{Th}(\mathrm{ppm})$ & ${ }^{40} \mathrm{~K}(\%)$ & ${ }^{238} \mathrm{U}(\mathrm{ppm})$ & ${ }^{232} \mathrm{Th}(\mathrm{ppm})$ & ${ }^{40} \mathrm{~K}(\%)$ & ${ }^{238} \mathrm{U}(\mathrm{ppm})$ & ${ }^{232} \mathrm{Th}(\mathrm{ppm})$ & ${ }^{40} \mathrm{~K}(\%)$ \\
\hline \multirow[t]{2}{*}{ Manzanares valley } & PRERESA & PRE0501 & $0.410 \pm 0.070$ & $1.530 \pm 0.080$ & $3.770 \pm 0.103$ & $4.380 \pm 0.138$ & $18.949 \pm 0.223$ & $4.783 \pm 0.029$ & & & \\
\hline & & PRE0502 & $0.430 \pm 0.070$ & $1.460 \pm 0.078$ & $4.210 \pm 0.115$ & $5.202 \pm 0.113$ & $19.930 \pm 0.181$ & $4.194 \pm 0.022$ & & & \\
\hline \multirow{7}{*}{ Jarama valley } & Valdocarros & VDC0501 & $0.340 \pm 0.070$ & $1.130 \pm 0.068$ & $2.090 \pm 0.057$ & $2.188 \pm 0.087$ & $7.222 \pm 0.124$ & $3.502 \pm 0.020$ & & & \\
\hline & & VDC0502 & $0.260 \pm 0.069$ & $0.850 \pm 0.060$ & $2.050 \pm 0.056$ & $1.361 \pm 0.075$ & $4.435 \pm 0.099$ & $3.947 \pm 0.020$ & & & \\
\hline & & VDC0503 & $0.240 \pm 0.069$ & $0.960 \pm 0.063$ & $0.905 \pm 0.025$ & $1.677 \pm 0.093$ & $5.841 \pm 0.136$ & $2.599 \pm 0.021$ & & & \\
\hline & & VDC0504 & $0.300 \pm 0.069$ & $1.310 \pm 0.073$ & $1.590 \pm 0.043$ & $2.565 \pm 0.080$ & $8.904 \pm 0.120$ & $2.283 \pm 0.015$ & & & \\
\hline & Maresa & MA0501 & $0.110 \pm 0.069$ & $1.310 \pm 0.073$ & $0.246 \pm 0.007$ & $1.678 \pm 0.093$ & $6.134 \pm 0.132$ & $3.115 \pm 0.022$ & & & \\
\hline & & MA0502 & $0.320 \pm 0.069$ & $1.400 \pm 0.076$ & $1.400 \pm 0.038$ & $1.169 \pm 0.095$ & $4.106 \pm 0.124$ & $3.735 \pm 0.026$ & & & \\
\hline & & TOL1212 & $0.350 \pm 0.070$ & $1.530 \pm 0.080$ & $0.107 \pm 0.003$ & & & & $0.920 \pm 0.076$ & $3.470 \pm 0.153$ & $3.702 \pm 0.101$ \\
\hline
\end{tabular}

Table 3

Q-ICP-MS U-series data $( \pm 2 \sigma)$, Rn losses and samples thicknesses $( \pm 1 \sigma)$ determined on teeth from Preresa (Manzanares valley) and Valdocarros (Jarama valley) sites.

\begin{tabular}{|c|c|c|c|c|c|c|c|c|c|}
\hline & \multicolumn{4}{|l|}{ Manzanares valley } & \multicolumn{5}{|l|}{ Jarama valley } \\
\hline & \multicolumn{4}{|l|}{ PRERESA } & \multicolumn{5}{|l|}{ Valdocarros } \\
\hline & \multicolumn{2}{|l|}{ PRE0701 } & \multicolumn{2}{|l|}{ PRE0702 } & \multicolumn{2}{|l|}{ VDC0702 } & \multicolumn{3}{|l|}{ VDC0703 } \\
\hline & Enamel & Dentine & Enamel & Dentine & Enamel & Dentine & Enamel & Dentine & Cement \\
\hline U content (ppm) & $5.319 \pm 0.009$ & $485.09 \pm 9.36$ & $4.90 \pm 0.01$ & $458.08 \pm 8.85$ & $4.45 \pm 0.01$ & $297.96 \pm 1.40$ & $2.82 \pm 0.01$ & $189.83 \pm 1.08$ & $359.47 \pm 3.03$ \\
\hline${ }^{234} \mathrm{U} /{ }^{238} \mathrm{U}$ & $1.2351 \pm 0.0024$ & $1.2597 \pm 0.0145$ & $1.2825 \pm 0.0027$ & $1.3454 \pm 0.0132$ & $1.1421 \pm 0.0021$ & $1.3907 \pm 0.0048$ & $1.3474 \pm 0.0036$ & $1.3423 \pm 0.0046$ & $1.4317 \pm 0.0046$ \\
\hline${ }^{230} \mathrm{Th} /{ }^{232} \mathrm{Th}$ & $>100$ & $>100$ & $>100$ & $>100$ & $>100$ & $>100$ & $>100$ & $>100$ & $>100$ \\
\hline${ }^{230} \mathrm{Th} /{ }^{234} \mathrm{U}$ & $0.7331 \pm 0.0037$ & $0.9546 \pm 0.0285$ & $0.8128 \pm 0.0054$ & $0.8731 \pm 0.0243$ & $0.9928 \pm 0.0047$ & $0.9949 \pm 0.0127$ & $0.9877 \pm 0.0050$ & $1.0187 \pm 0.0080$ & $1.11011 \pm 0.0122$ \\
\hline${ }^{222} \mathrm{Rn} /{ }^{230} \mathrm{Th}$ & 0.259 & 0.304 & 0.996 & 0.308 & 0.446 & 0.329 & 0.504 & 0.610 & 0.285 \\
\hline Initial thickness $(\mu \mathrm{m})$ & $1103 \pm 138$ & & $1484 \pm 185$ & & $1474 \pm 184$ & & $1465 \pm 183$ & & \\
\hline $\begin{array}{l}\text { Removed thickness } \\
\text { Internal side }(\mu \mathrm{m})\end{array}$ & $39 \pm 5$ & & $163 \pm 20$ & & $200 \pm 25$ & & $154 \pm 19$ & & \\
\hline $\begin{array}{l}\text { Removed thickness } \\
\text { External side }(\mu \mathrm{m})\end{array}$ & $97 \pm 12$ & & $160 \pm 20$ & & $183 \pm 23$ & & $146 \pm 18$ & & \\
\hline
\end{tabular}


calibrated source (LNHB, CEA, CEN Saclay, France) at doses ranging from to ca. $110-32000 \mathrm{~Gy}$.

\subsubsection{ESR dose reconstruction}

The ESR intensity of these aliquots and of a remnant natural aliquot were measured at least three times for each dose on different days using a EMX Bruker X-band spectrometer at MNHN (Paris, France) with the following measurement conditions at room temperature: microwave power $=10 \mathrm{~mW}$, modulation amplitude $=0.1 \mathrm{mT}$, scan range $=10 \mathrm{mT}$, scan time $=2 \mathrm{~min}$ for five scans, frequency modulation $=100 \mathrm{kHz}$. ESR intensities were derived from peak-to-peak amplitude measurement between T1 and B2 peaks (Grün, 2000). The equivalent doses were then extrapolated from the obtained dose response curve (DRC) using a double saturation exponential function (DSE) (Duval, 2015).

\subsubsection{Dose rate evaluation and age calculation}

In order to determine the U-uptake parameters necessary to the dose rate contributions and age calculations (Shao et al., 2015), U-series analyses were performed on each dental tissue by Q-ICPMS (Douville et al., 2010) following the chemical protocol of Shao et al. (2011): dissolution of 50-150 mg of each sample in 7N HNO3 and addition of ${ }^{233} \mathrm{U},{ }^{236} \mathrm{U}$ and ${ }^{229} \mathrm{Th}$ spike; elution of the solution through an anion exchange resin column (Dowex $1 \times 8 ; 100-200$ mesh) in $8 \mathrm{~N} \mathrm{HCl}$ condition allowing thorium to be recovered and uranium to be to retained; elution of uranium is performed using $0.1 \mathrm{~N} \mathrm{HCl}$; purification of $U$ and Th fractions using respectively a UTEVA resin column in $7 \mathrm{~N} \mathrm{HNO3}$ and a second anion exchange resin column in $7 \mathrm{~N} \mathrm{HNO3,} \mathrm{then} \mathrm{elution} \mathrm{with} 0.1 \mathrm{~N} \mathrm{HCl}$ for $\mathrm{U}$ and $8 \mathrm{~N}$ $\mathrm{HCl}$ for Th; evaporation of the purified $\mathrm{U}$ and Th isolates, dissolution of residues in $0.5 \mathrm{~N} \mathrm{HNO} 3$ and recombination before the ICPQMS analyses. U-series results are displayed in Table 3. Gamma spectrometry measurements were also made on each dental tissue to evaluate eventual radon losses (Bahain et al., 1992). The beta dose contributions were calculated taking into account a correction linked to the part removed from each side of the enamel layer during the preparation process (according to Brennan et al., 1997) (Table 3).

The radioelement contents of sediment samples associated to the archaeological levels were determined in laboratory by low background high purity gamma spectrometry measurements. The cosmic dose rate was estimated using the formula of Prescott and Hutton (1994). A fixed value of $15 \pm 5 \%$ was therefore used for the age calculations. The following parameters were also used: a kvalue ( $\alpha$ efficiency) of $0.13 \pm 0.02$ (Grün and Katzenberger-Apel, 1994); water content of 0 wt\% in enamels and $7 \mathrm{wt} \%$ in dentines and cements; dose rate conversion factors from Adamiec and Aitken (1998). The "US/AU-ESR" computer program (Shao et al., 2012, 2014) was used for the age calculation. This software allows the calculation of ESR/U-series ages with both US (Grün, 2009) and AU (Shao et al., 2012) models, i.e. considering respectively post-mortem U-uptake or both U-Uptake and U-leaching if weak uranium loss are observed. The ESR/U-series data, dose rate contributions and ages are displayed at Table 4.

\section{Results}

\subsection{Combined US-ESR dating of fossil teeth}

For PRERESA samples, the tissues of the two analyzed teeth display relatively recent U-uptake allowing the use of US model for PRE0702 tooth and the calculation of a p-parameter for the enamel of PRE0701. The resulting ages for these two teeth are highly consistent, with $206 \pm 42 \mathrm{ka}$ and $235 \pm 32$ ka respectively. In contrast, the Valdocarros teeth show apparent uranium

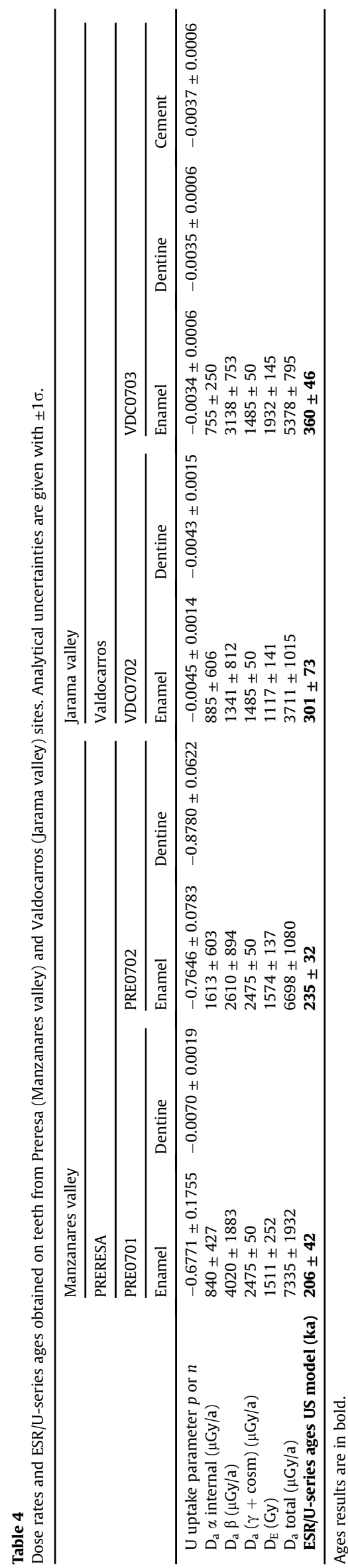


Table 5

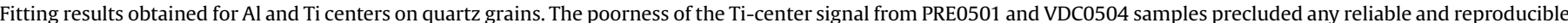

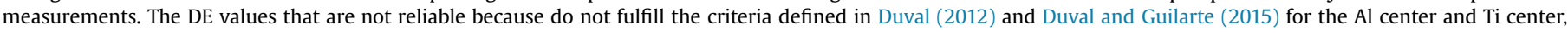
respectively are given in italics. The DE values used for age calculations are given in bold.

\begin{tabular}{|c|c|c|c|c|c|c|c|c|c|c|c|c|}
\hline & & \multicolumn{2}{|l|}{ Function } & \multirow{2}{*}{\multicolumn{2}{|c|}{$\frac{\text { Manzanares valley }}{\text { PRERESA }}$}} & \multicolumn{7}{|l|}{ Jarama valley } \\
\hline & & & & & & \multicolumn{4}{|l|}{ Valdocarros } & \multicolumn{3}{|l|}{ Maresa } \\
\hline & & & & PRE0501 & PRE0502 & VDC0501 & VDC0502 & VDC0503 & VDC0504 & MA0501 & MA0502 & TOL1212 \\
\hline \multirow{2}{*}{\multicolumn{2}{|c|}{ Al center }} & SSE + LIN & Adj. $\mathrm{R}^{2}$ & 0.983 & 0.985 & 0.991 & 0.996 & 0.991 & 0.995 & 0.980 & 0.995 & 0.994 \\
\hline & & & $\mathrm{D}_{\mathrm{E}}(\mathrm{Gy})$ & $1085 \pm 315$ & $1609 \pm 328$ & $1366 \pm 214$ & $1101 \pm 131$ & $2610 \pm 446$ & $900 \pm 122$ & $782 \pm 197$ & $790 \pm 83$ & $888 \pm 112$ \\
\hline \multirow[t]{6}{*}{ Ti-Li center } & D Option & Ti2 & Adj. $\mathrm{R}^{2}$ & - & 0.985 & 0.989 & 0.989 & 0.922 & - & 0.947 & 0.999 & 0.996 \\
\hline & & & $\mathrm{D}_{\mathrm{E}}(\mathrm{Gy})$ & - & $1440 \pm 216$ & $1194 \pm 269$ & $1233 \pm 232$ & $1156 \pm 482$ & - & $1492 \pm 422$ & $548 \pm 63$ & $570 \pm 29$ \\
\hline & A Option & Ti2 & Adj. $\mathrm{R}^{2}$ & - & 0.992 & 0.996 & 0.985 & 0.973 & - & 0.965 & 0.997 & 0.996 \\
\hline & & & $\mathrm{D}_{\mathrm{E}}(\mathrm{Gy})$ & - & $2085 \pm 248$ & $1360 \pm 99$ & $1120 \pm 236$ & $1051 \pm 236$ & - & $1283 \pm 317$ & $662 \pm 68$ & $785 \pm 40$ \\
\hline & E Option & Ti2 & Adj. $\mathrm{R}^{2}$ & - & 0.767 & 0.957 & 0.956 & 0.928 & - & 0.948 & 0.997 & 0.985 \\
\hline & & & $\mathrm{D}_{\mathrm{E}}(\mathrm{Gy})$ & - & $2276 \pm 1518$ & $1032 \pm 262$ & $904 \pm 316$ & $706 \pm 315$ & - & $1370 \pm 445$ & $550 \pm 113$ & $1048 \pm 82$ \\
\hline \multirow[t]{2}{*}{ Ti-H center } & C option & Ti2 & Adj. $\mathrm{R}^{2}$ & - & 0.834 & 0.960 & 0.747 & 0.211 & - & 0.746 & 0.890 & 0.976 \\
\hline & & & $\mathrm{D}_{\mathrm{E}}(\mathrm{Gy})$ & - & $436 \pm 177$ & $543 \pm 208$ & $1207 \pm 791$ & $355 \pm 508$ & - & $1145 \pm 655$ & $212 \pm 111$ & $322 \pm 53$ \\
\hline
\end{tabular}

leaching in all tissues, precluding thus the use of the US model. Consequently, the AU model was systematically used for all the tissues. The AU-ESR ages obtained for the two analysed teeth are highly consistent, with $301 \pm 73$ ka and $360 \pm 46$ ka for VDC0702 and VDC0703 respectively.

\subsection{ESR dating of optically bleached quartz grains}

The ESR analytical data are listed in Tables 2, 5 and 6. All the ESR DRCs derived from the evaluation of the Al., Ti-Li and Ti-H centers are provided in supplementary information (Fig. S1-S5). It should be mentioned here that no reliable ESR data could be obtained from the Ti centers of samples PRE0501 and VDC0504 given the very weak ESR signal.

\subsubsection{Fitting results}

Regarding the Al center, the dose equivalent $\left(D_{E}\right)$ values were calculated by considering for each aliquot the average ESR intensities obtained from the three repeated measurements carried out over three days. According to Duval (2012), the reliability of the fitting results obtained from the Al center may be reasonably questioned when the adjusted $r^{2}$ value is $<0.99$ and the relative errors on the fitted parameters $>25 \%$. This is the case for some of the samples of the present study, like the two from PRERESA site (PRE0501 and PRE0502, Table 5) in the Manzanares valley. This is contrasting with the fitting results derived from the samples of the Jarama valley (Valdocarros and Maresa) that show adjusted $r^{2}$ values of 0.99 and the relative $\mathrm{D}_{\mathrm{E}}$ errors are ranging from $10 \%$ to $17 \%$, with the exception of the sample MA0501.

According to Duval and Guilarte (2015), the $\mathrm{D}_{\mathrm{E}}$ obtained from the Ti center should fulfill two criteria in order to confirm their reliability: the adjusted $\mathrm{r}^{2}$ value should be greater than 0.98 and the relative errors on the fitted parameters lower than $50 \%$. In our samples, options A and D show adjusted $r^{2}$ values systematically higher than 0.98 indicating a high goodness-of-fit and errors ranging between $7 \%$ and $22 \%$, the exception being VDC0503 and MA0501 (options A and D: $\mathrm{r}^{2}<0.98$ and errors $>22 \%$ ). Options A and $\mathrm{D}$ provide overall consistent $\mathrm{D}_{\mathrm{E}}$ values for all the samples. The highest differences may be observed for samples PRE0502 and TOL1212, for which option A leads to significantly higher $D_{E}$ values. This is due to the peak at $\mathrm{g}=1.979$ which, taken alone (option $\mathrm{E}$ ), provides much higher $D_{E}$ values. However, the poor goodness-of-fit observed for most of the samples precludes any further interpretation of those data. Following the work by Duval and Guilarte (2015), final $D_{E}$ were calculated considering the ESR intensities taken from option $\mathrm{D}$.

Ti-H center (option C) has also been measured and the fitting results are provided in Table 5 . This center potentially offers many interests for dating purpose (Duval et al., 2017) but the reliability of the fitting results obtained in the present study may be strongly questioned, given the systematic very poor goodness-of-fit observed ( $\mathrm{r}^{2}$ ranging between 0.21 and 0.96 ). Consequently, any further comparison with the results derived from the other centres would therefore result meaningless, and no age calculation was

Table 6

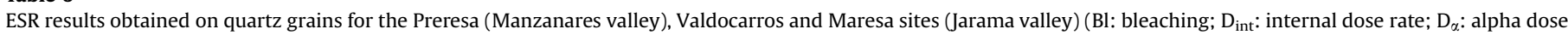
rate; $\mathrm{D}_{\beta}$ : beta dose rate; $\mathrm{D}_{\gamma}$ : gamma dose rate; $\mathrm{D}_{\text {cos }}$ : cosmic dose rate; $\mathrm{D}_{\mathrm{a}}$ : total dose rate; $\mathrm{D}_{\mathrm{E}}$ : equivalent dose).

\begin{tabular}{|c|c|c|c|c|c|c|c|c|c|}
\hline & \multicolumn{2}{|c|}{ Manzanares valley } & \multicolumn{7}{|l|}{ Jarama valley } \\
\hline & \multicolumn{2}{|l|}{ PRERESA } & \multicolumn{4}{|l|}{ Valdocarros } & \multicolumn{3}{|l|}{ Maresa } \\
\hline & PRE0501 & PRE0502 & VDC0501 & VDC0502 & VDC0503 & VDC0504 & MA0501 & MA0502 & TOL1212 \\
\hline Depth (cm) & 500 & 300 & 1600 & 1100 & 850 & 400 & 1000 & 350 & 110 \\
\hline $\mathrm{Bl}(\%)$ & $51 \pm 1$ & $57 \pm 6$ & $51 \pm 1$ & $54 \pm 4$ & $53 \pm 2$ & $46 \pm 1$ & $55 \pm 1$ & $40 \pm 3$ & $46 \pm 1$ \\
\hline $\operatorname{Dint}(\mu \mathrm{Gy} / \mathrm{a})$ & $471 \pm 24$ & $490 \pm 25$ & $330 \pm 17$ & $271 \pm 14$ & $224 \pm 11$ & $311 \pm 16$ & $183 \pm 9$ & $319 \pm 16$ & $169 \pm 10$ \\
\hline $\mathrm{D} \alpha(\mu \mathrm{Gy} / \mathrm{a})$ & $139 \pm 5$ & $153 \pm 6$ & $59 \pm 2$ & $37 \pm 1$ & $47 \pm 2$ & $71 \pm 2$ & $48 \pm 2$ & $33 \pm 1$ & $20 \pm 5$ \\
\hline $\mathrm{D} \beta(\mu \mathrm{Gy} / \mathrm{a})$ & $3956 \pm 158$ & $3687 \pm 140$ & $2651 \pm 114$ & $2792 \pm 128$ & $1983 \pm 85$ & $1939 \pm 76$ & $2323 \pm 101$ & $2627 \pm 121$ & $2611 \pm 71$ \\
\hline $\mathrm{D} \gamma(\mu \mathrm{Gy} / \mathrm{a})$ & $2271 \pm 69$ & $2758 \pm 276$ & $1280 \pm 42$ & $1175 \pm 44$ & $976 \pm 32$ & $1126 \pm 34$ & $1099 \pm 37$ & $1096 \pm 42$ & $1020 \pm 60$ \\
\hline $\operatorname{Dcos}(\mu \mathrm{Gy} / \mathrm{a})$ & $89 \pm 4$ & $120 \pm 6$ & $27 \pm 1$ & $42 \pm 2$ & $56 \pm 3$ & $103 \pm 5$ & $47 \pm 2$ & $111 \pm 6$ & $191 \pm 19$ \\
\hline $\mathrm{Da}(\mu \mathrm{Gy} / \mathrm{a})$ & $6926 \pm 174$ & $7208 \pm 310$ & $4347 \pm 123$ & $4317 \pm 136$ & $3286 \pm 91$ & $3550 \pm 84$ & $3700 \pm 108$ & $4185 \pm 129$ & $4011 \pm 96$ \\
\hline $\mathrm{DE}(\mathrm{Gy}) \mathrm{Al}$ & $1085 \pm 315$ & $1609 \pm 328$ & $1366 \pm 214$ & $1101 \pm 131$ & $2610 \pm 446$ & $900 \pm 122$ & $782 \pm 197$ & $790 \pm 83$ & $888 \pm 112$ \\
\hline DE (Gy) Ti-Li D option & - & $1440 \pm 216$ & $1194 \pm 269$ & $1233 \pm 232$ & $1156 \pm 482$ & - & $1492 \pm 422$ & $548 \pm 63$ & $570 \pm 29$ \\
\hline Age (ka) Al & $157 \pm 46$ & $223 \pm 47$ & $314 \pm 50$ & $255 \pm 31$ & $794 \pm 138$ & $254 \pm 35$ & $211 \pm 54$ & $189 \pm 21$ & $221 \pm 28$ \\
\hline Age (ka) Ti-Li D option & - & $200 \pm 31$ & $275 \pm 62$ & $286 \pm 54$ & $352 \pm 147$ & - & $403 \pm 115$ & $131 \pm 16$ & $142 \pm 8$ \\
\hline
\end{tabular}

Ages results are in bold. 
carried out for the Ti-H centre.

\subsubsection{Internal dose rate}

In ESR dating of quartz grains, the internal dose rate is generally assumed to be negligible since quartz is considered free of radioactive elements. However, several studies have shown that this assumption may sometimes be wrong. For example, Sutton and Zimmerman (1978) carried out a few $\alpha$-activity measurements on quartz extracts which yielded internal dose rates in the range of about $60-200 \mu \mathrm{Gy} / \mathrm{a}$.

In the present study, ICP-MS analysis was systemically performed on the prepared quartz grain samples in order to evaluate their radioelement concentrations (see Table 2). Values obtained for the nine samples range between 0.11 and $0.43 \mathrm{ppm}$ of $U$ and $0.85-1.53 \mathrm{ppm}$ of $\mathrm{Th}$, which result in internal dose rates ranging from $183 \pm 9$ to $490 \pm 25 \mu \mathrm{Gy} / \mathrm{a}$ (Table 6). This is actually an important contribution to the total dose rate (5 to about $7 \%$ ), which results in a non-negligible impact on the final age results. These high radioelement concentrations may also indicate a possible contamination of the sample by feldspar.

\subsubsection{ESR age estimates}

5.2.3.1. PRERESA (PRE) site (Manzanares valley). For PRE0501, located on the bottom of the local stratigraphic sequence, only an ESR age ( $157 \pm 46 \mathrm{ka}$ ) based on the Al center was obtained because the Ti center could not be measured. The poor reliability of the fitting results may explain the inconsistency of this age with the stratigraphy. In the case of PRE0502 located above, both the $\mathrm{Al}$ and Ti centres provide consistent results of $223 \pm 47 \mathrm{ka}$ and $200 \pm 31 \mathrm{ka}$, respectively. These ages estimates are in agreement with the ESR results obtained on teeth $(206 \pm 42 \mathrm{ka}$ and $235 \pm 32 \mathrm{ka})$, suggesting an early MIS 7 chronology (Tables 4 and 6).

5.2.3.2. Valdocarros (VDC) site (Jarama valley). In the Arganda I unit, the two ESR ages obtained for VDC0501 (ESR-Al: $314 \pm 50 \mathrm{ka}$; ESRTi: $275 \pm 62 \mathrm{ka}$ ) are consistent at $1 \sigma$, although the ESR-Ti age is younger than the ESR-Al. This might be due to an incomplete bleaching of the signal of the $\mathrm{Al}$ center during sediment transport, as the bleaching kinetics of the Ti centers is known to be much faster than that of the Al center (Toyoda et al., 2000). However, this age difference may also be interpreted as being not significant, given the associated errors.

In the Arganda II unit, two ESR ages on optically bleached quartz (VDC0502: $255 \pm 31 \mathrm{ka}, \mathrm{Al}$ center and $286 \pm 54 \mathrm{ka}$, Ti center) and two ESR/U-series ages (VDC0703: $301 \pm 73$ and VDC0702: $360 \pm 40$ ka) have been obtained for the excavation level. Again, both $\mathrm{Al}$ and $\mathrm{Ti}$ centers provide consistent results at $1 \sigma$. These are also in agreement with two out of three AAR ages obtained on ostracods and herbivores molars ( $254 \pm 47 \mathrm{ka} ; 262 \pm 7 \mathrm{ka} ; 174 \pm 20 \mathrm{ka})$ (Panera et al., 2011). The corresponding ESR/U-series ages on teeth are somewhat older, but nevertheless do not disagree with the other data at $2 \sigma$.

For Arganda III unit, the ESR quartz ages estimates for VDC0503 are very scattered, with $794 \pm 138 \mathrm{ka}$ (Al center) and $352 \pm 147 \mathrm{ka}$ (Ti center). Neither of these ages are consistent with the existing chronology of the terrace sequence at the Jarama valley in which the T14 (+18-20 m; Arganda III unit) has been ascribed to the Upper Pleistocene. Additionally, both Al and Ti center ages seem to be strongly overestimated in comparison with the results obtained for Arganda I and II. This may be explained by the poor fitting results of these samples since in both cases the curve pass over the natural point (see SI). Consequently, we consider that none of these ages may be considered as reliable.

Finally, the sample VDC0504 (Arganda IV unit) has yielded only an ESR quartz age of $254 \pm 35$ ka based on the $D_{E}$ value derived from the Al center. This ESR result is not consistent with both the stratigraphy and the previous chronological data which suggest an age ranging between $112+36-22$ to $74 \pm 5$ ka (Upper Pleistocene, MIS5) (Panera et al., 2005, 2011). An incomplete bleaching of the Al center prior to sediment deposition could explain this overestimation, but unfortunately the Ti-center age could not be measured to confirm this hypothesis. In any case, the ESR result available should be considered as a maximum possible age for Arganda IV.

5.2.3.3. Maresa (MA) quarry (Jarama valley). The ESR age estimates for the Arganda I unit (MA0501 sample) in Maresa are quite scattered, with $211 \pm 54 \mathrm{ka}$ and $403 \pm 115 \mathrm{ka}$ for $\mathrm{Al}$ and Ti centers, respectively. It is actually quite unusual to observe a $\mathrm{Ti}$ age result significantly older than the Al equivalent for a given sample. Because of their placement downstream of the confluence of the Jarama and Manzanares rivers, sediments may be contaminated by older deposits, although it should be mentioned here that the poor goodness-of-fit achieved for both the $\mathrm{Al}$ and Ti signals may induce some uncertainty regarding the reliability of the age results obtained. Any further interpretation of those ESR results should be considered with caution.

In Arganda III unit, the ESR ages calculated for the MA0502 (ESRAl: $189 \pm 21 \mathrm{ka}$; ESR-Ti: $131 \pm 16 \mathrm{ka}$ ) and for TOL1212 (ESR-Al: $221 \pm 28 \mathrm{ka}$; ESR-Ti: $142 \pm 8 \mathrm{ka}$ ) samples are consistent within uncertainties. The difference in the $\mathrm{Al}$ and $\mathrm{Ti}$ ages may be interpreted as an evidence of an incomplete bleaching of the Al center prior to sediment deposition. It is worth pointing out that the sample MA0502 shows an extremely high goodness-of-fit for the Ti-center. The adjusted $r^{2}$ values are systematically higher than 0.98 (0.999 for option D, 0.997 for option A and 0.994 for option E) and the $D_{E}$ values obtained from these three options are all very close $(548 \pm 63$ for option D, $662 \pm 68$ for option A and $550 \pm 113$ for option E). Taking into account these data, the ESR-Ti center seems to provide the most likely estimation of the true age of the Arganda III unit at Maresa quarry.

\section{Discussion}

\subsection{Refining the chronology of the PRERESA site (Manzanares valley)}

Previous studies pointed out a younger chronology for PRERESA. For example, the small mammal assemblage of PRERESA would be characteristic of the first half of the Upper Pleistocene, mainly due to the presence of M. cabrerae (Sesé et al., 2011a), and besides, OSL dating provided an age of $84 \pm 5.6 \mathrm{ka}$ (Yravedra et al., 2012). The first records of populations of Microtus cabrerae are found at the Middle-Late Pleistocene transition localities of southern France such as Payre (levels F and G) (Desclaux et al., 2008). These levels have TL dates of $232 \pm 15 \mathrm{ka}$ and $231 \pm 27 \mathrm{ka}$, respectively and, levels F-G together were dated by Uranium-series to $235 \pm 18$ ka (Falguères et al., 2008). Nevertheless, recently, the micromammal association of Payre has been related with MIS 6-5 transition (Foury et al., 2016). In the Iberian Peninsula, the first record of this species has been assigned to the Upper Pleistocene. In the Arriaga sand quarry, at the Complex Terrace of Butarque (CTB), the two TL samples which provided minimum ages of $133 \mathrm{ka}$ and $134 \mathrm{ka}$ (Silva et al., 2012) were taken at the same place where Microtus brecciensis was recorded (Sesé and López-Martínez, 2013), above Arriaga I (Silva et al., 2011). Although others authors attribute those remains to Microtus cabrerae (Laplana et al., 2015), the relationship between these ages and Arriaga I should be considered with caution as they were obtained from samples taken more than 30 years after the excavation of the site and it is difficult to correlate 
these ages with the micrommamal assemblage. On the other hand, the mammal remains at Arriaga IIa above Arriaga I site (Elephas (P.) antiquus, Bos primigenius, Equus caballus, Cervus elaphus and Dicerorhinus hemitoechus), belong to the typical Middle Pleistocene assemblage of the Madrid region (Sesé and Soto, 2000).

If the attribution and the chronology for Arriaga I are confirmed, it would be in agreement with the ESR ages presented in this work suggesting that the PRERESA site, and so the outcrop Complex Terrace of Butarque, may be somewhat older than previously expected, belonging to the end of the Middle Pleistocene. Taking into account that Microtus brecciensis is the direct ancestor of Microtus cabrerae (Cabrera-Millet et al., 1982), which gradually reduced its distribution range from the late Pleistocene to the present (LópezMartínez, 2009), and that at Mollet there is an isochron age for Layer 5 with Microtus brecciensis of 215 ka, provided by uraniumseries method (Maroto et al., 2012; López-García et al., 2014), the most likely chronology for PRERESA site is the youngest age of its range (169-270 ka). It would therefore be the beginning of MIS 6 .

Consequently, the chronological distribution of Microtus cabrerae would more likely cover from the late Middle Pleistocene to the Holocene, making PRERESA site (Manzanares valley) the oldest record of this species in the Iberian Peninsula (Fig. 7).
6.2. Geomorphological interpretation of the ESR age results at the Jarama valley

As described in section 2.2, the Arganda Complex Terrace (TCA), located in the low valley of Jarama river and where the Valdocarros (VDC) and Maresa (MA) sites were discovered, is formed by successive alluvial deposits identified as Arganda I, II, III and IV, from bottom to top. One of the main aims of this work was to improve the current chronostratigraphic framework of these alluvial deposits (Arganda units) (Fig. 8).

Taking into account the ESR ages obtained in the present work for Arganda I at Valdocarros site (VDC0501: $314 \pm 50 \mathrm{ka}$ and $275 \pm 62 \mathrm{ka}$ ) and the previous Amino Acid Racemization ages (AAR) obtained at Maresa site ( $332 \pm 38 \mathrm{ka}$ and $379 \pm 45 \mathrm{ka}$ ) (Panera et al., 2011) an age ranging between 295 and 365 ka (MIS10-9) may be the most likely estimation of the true age for this unit. The limits of this age range have been located where there is a greater number of age overlap (Fig. 8). The ESR ages estimates for this unit at Maresa quarry (MA0501: $211 \pm 54 \mathrm{ka}$ and $403 \pm 115 \mathrm{ka}$ ) have not been taking into account because of their poor reliability. Proceeding as in the Arganda I and using the ESR ages on quartz (ESR-Al: $255 \pm 31$ ka; ESR-Ti-Li: $286 \pm 54 \mathrm{ka})$ and the ESR ages on teeth (360 $\pm 46 \mathrm{ka}$

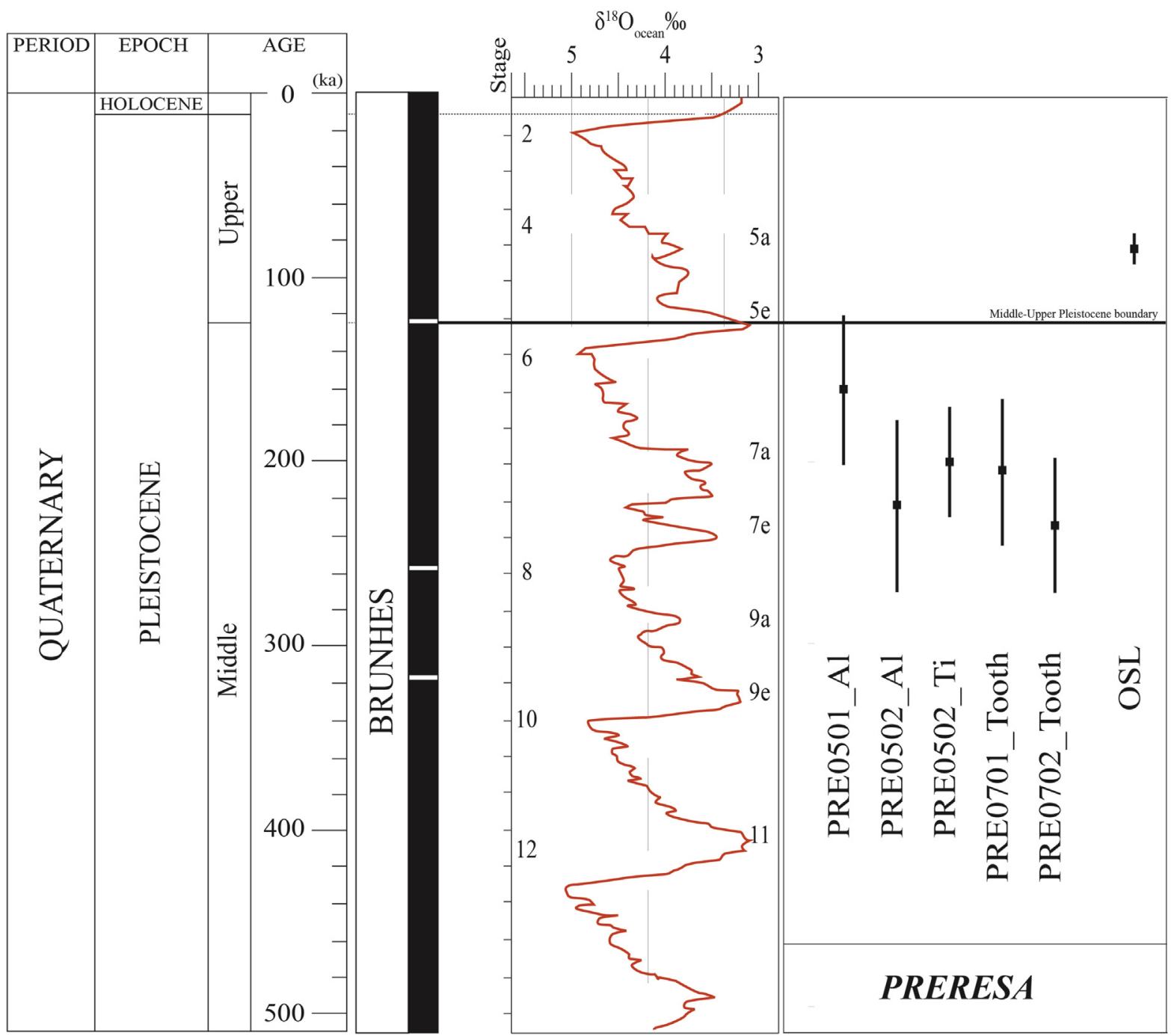

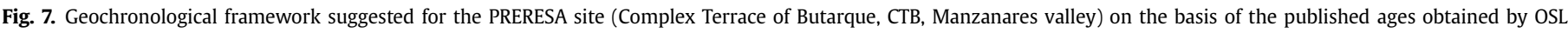
(Yravedra et al., 2012; Panera et al., 2014) and the ESR ages obtained in the present work. 


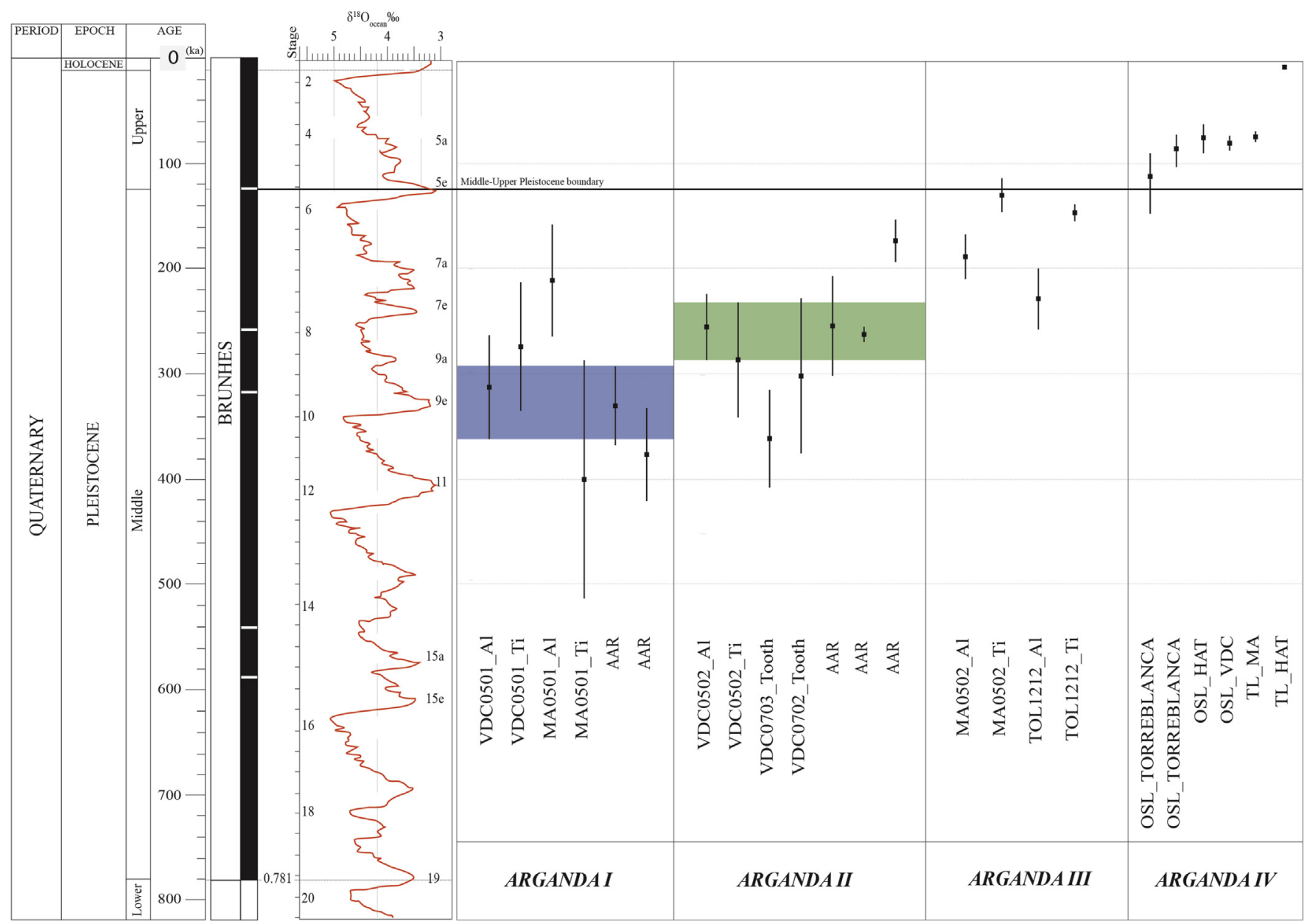

Fig. 8. Geochronological framework suggested for the Arganda I, II, III and IV units (Arganda Complex Terrace, TCA, Jarama valley) on the basis of the published ages obtained by TL, OSL and AAR (Panera et al., 2011) and the ESR ages obtained in the present work.

and $301 \pm 73 \mathrm{ka}$ ) obtained in this work and the previous AAR ages $(254 \pm 47 \mathrm{ka}, 262 \pm 07 \mathrm{ka}$ and $174 \pm 20 \mathrm{ka})$ at Valdocarros site (Panera et al., 2011), an age range between 235 and 285 ka (MIS8) could be given for the Arganda II unit. In the Arganda III unit, only the ESR ages on quartz obtained at Maresa quarry: MA0502 (Al: $189 \pm 21 \mathrm{ka}$ and Ti-Li: $131 \pm 16 \mathrm{ka})$ and TOL1212 (Al: $228 \pm 29 \mathrm{ka}$ and Ti-Li: $146 \pm 8 \mathrm{ka}$ ) can be used because of the inconsistency of the results derived from the sample VDC0503 at Valdocarros site. In that regard, the difference in the $\mathrm{Al}$ and $\mathrm{Ti}$ ages for these samples has been interpreted as an evidence of an incomplete bleaching of the Al. Therefore, the ESR-Al ages of $228 \pm 29 \mathrm{ka}$ and $189 \pm 21 \mathrm{ka}$ should be considered as maximum possible age estimates for this unit while the ESR ages derived from the Ti center $(146 \pm 8 \mathrm{ka}$ and $131 \pm 16 \mathrm{ka}$ ) would provide the more correct estimation of the true age suggesting that the Arganda III unit was deposited during the MIS6. Finally, the ESR data provided by the sample VDC0504 at Valdocarros site is inconsistent with stratigraphy and paleontological data available. The age of the Arganda IV unit is therefore given by the previous chronological data obtained by OSL and TL at different localities (HAT, Torreblanca, Maresa y Valdocarros) (Panera et al., 2005, 2011) which suggest a clear chronological position to the Arganda IV to the Upper Pleistocene (MIS5). This unit Arganda IV is a slope deposit which transportation process is not favorable for ESR dating.

\section{Conclusion}

This study presents several ESR ages (quartz and teeth) for three archaeological sites located on the fluvial deposits of the Manzanares River (PRERESA site) and the Jarama River (Valdocarros site and Maresa quarry) to the southeast of Madrid (Central Spain). The ESR dating study presented in this work suggests that the PRERESA site (Manzanares valley) may be somewhat older than previously expected, belonging to the end of the Middle Pleistocene (early MIS6). The numerical ages obtained at the Jarama valley show good consistency with previous chronological data, stratigraphy and micro-mammals for the Arganda I, II and III units. Consequently, based on the results obtained in the present work, Arganda I unit may be chronologically positioned between MIS10 and MIS9, Arganda II unit between MIS8 and MIS7 and Arganda III close to the MIS6. In contrast, the results obtained for Arganda IV are inconsistent with both stratigraphy and previous numerical ages. To complete those ESR results, more samples should be taken in the future, especially for the upper Arganda alluvial units (Arganda III and IV).

To conclude, the present work contributes to refine the chronology of three important Palaeolithic sites and to reinforce the chronological framework of two of the most important tributaries rivers of the Tagus River. The age scattering observed in the Arganda III and IV demonstrates the necessity to take more than 
one sample to get a reliable estimate of the chronology of a given archaeological site or deposit. These ESR dating study shows the interest of using ESR dating of optically bleached quartz grains extracted from fluvial sediments in order to calculate numerical ages for the whole Middle Pleistocene, as well as the importance of measuring both the Al- and Ti-centers in a given sample.

\section{Acknowledgments}

This research has been funded by the Dirección General de Patrimonio Histórico (PR170/04-13244; PR42/05-14071; 1962/ 2006/00) and the Dirección General de Investigación of the Comunidad de Madrid (06/123/2003). The authors wish to thank T. Garcia and J.M. Dolo (Commissariat à l'Energie Atomique, Paris, France) for the alanine irradiation and V. Guilarte for her support in the preparation of one of the samples. Financial support was provided to the Department of Prehistory of the Muséum National d'Histoire Naturelle by the Conseil Régional d'Ile-de-France for the acquisition of an ESR EMX Bruker spectrometer and by the Ministère de la Culture, sous-direction de l'Archéologie, Service Régional de l'Archéologie of the Region Centre (France) for the acquisition of a portable $\gamma$-spectrometer. M. Duval is currently the recipient of an Australian Research Council Future Fellowship (FT150100215).

\section{Appendix A. Supplementary data}

Supplementary data related to this article can be found at http:// dx.doi.org/10.1016/j.quaint.2017.09.003.

\section{References}

Adamiec, G., Aitken, M.J., 1998. Dose-rate conversion factors: update. Anc. TL 16 37-50.

Bahain, J.J., Yokoyama, Y., Falguères, C., Sarcia, M.N., 1992. ESR dating of tooth enamel: a comparison with K-Ar dating. Quat. Sci. Rev. 11, 245-250.

Bahain, J.J., Falguères, C., Laurent, M., 2012. ESR and ESR/U-series dating study of several middle Palaeolithic sites of Pléneuf-Val-André (Brittany, France): Piégu, Les Vallées and Nantois. Quat. Geochronol. 10, 424-429.

Benito, G., Gutiérrez, F., Pérez-González, A., Machado, M.J., 2000. Geomorphological and sedimentological features in Quaternary fluvial systems affected by solution-induced subsistence (Ebro basin, NE Spain). Geomorphology 33, 206-224.

Benito-Calvo, A., Pérez-González, A., Parés, J.M., 2008. Quantitative reconstruction of Late Cenozoic landscapes: a case study in the Sierra de Atapuerca (Burgos, Spain). Earth Surf. Process. Landforms 33, 196-208.

Blain, H.A., Panera, J., Uribelarrea, D., Rubio-Jara, S., Pérez-González, A., 2012 Characterization of a rapid climate shift at the MIS 8/7 transition in central Spain (Valdocarros II, Autonomous Region of Madrid) by means of the herpetological assemblages. Quat. Sci. Rev. 47, 73-81.

Blain, H.A., Sesé, C., Rubio-Jara, S., Panera, J., Uribelarrea, D., Pérez-González, A. 2013. Reconstruction paléoenvironnementale et paléoclimatique du Pléistocène supérieur ancien (MIS 5a) dans le centre de l'Espagne: les petits vertébrés (Amphibia, Reptilia \& Mammalia) des gisements de HAT et PRERESA (Sud-est de Madrid). Quaternaire 24 (2), 191-205.

Brennan, B.J., 2003. Beta doses to spherical grains. Radiat. Meas. 37 (4-5), 299-303.

Brennan, B.J., Lyons, R.G., Philips, S.W., 1991. Attenuation of alpha particle track dose for spherical grains. Int. J. Radiat. Appl. Instrum. Part D. Nucl. Tracks Radiat. Meas. 18, 249-253.

Brennan, B.J., Rink, W.J., McGuirl, E.L., Schwarcz, H.P., Prestwich, W.V., 1997. Beta doses in tooth enamel by "one-group" theory and the ROSY ESR dating software. Radiat. Meas. 27, 307-314.

Cabrera-Millet, M., Britton-Davidian, J., Orsini, P., 1982. Génétique biochimique comparée de Microtus cabrerae Thomas, 1906 et de trois autres espèces d'Arvicolidae mediterranéens. Mammalia 46 (3), 381-388.

De Vicente, G., Muñoz-Martín, A., 2013. The Madrid Basin and the Central System: tectonostratigraphic analysis from 2D seismic lines. Tectonophysics 602, 259-285.

De Vicente, G., González-Casado, J.M., Muñoz-Martín, A., Giner, J., Rodríguez Pascua, M.A., 1996. Structure and tertiary evolution of the Madrid basin. In Frien, P.F., Dabrio, C.J. (Eds.), Tertiary Basins of Spain: the Stratigraphic Record of Crustal Kinematics. University Press, Cambridge, pp. 263-267.

Desclaux, E., El Hazzazi, N., Villette, P., Dubar, M., 2008. Le contexte environnemental des occupations humaines. L'apport de la microfaune, des restes aviaires et de la malacofaune. In: Moncel, M.H. (Ed.), Le site de Payre: Occupations Humaines dans la vallée du Rhône à la fin du Pléistocène Moyen et au début du Pléistocène supérieur, Mémoires de la Société Préhistorique Française, vol. 46, pp. 91-105.

Dolo, J.M., Lecerf, N., Mihajlovic, V., Falguères, C., Bahain, J.J., 1996. Contribution of ESR dosimetry for irradiation of geological and archaeological samples with a ${ }^{60} \mathrm{Co}$ panoramic source. Appl. Radiat. Isotopes 47, 1419-1421.

Domínguez-Alonso, R.M. Arcos Fernández, S, Ruiz Zapata, B. Gil García, M.J., 2009. Nuevos datos sobre la Terraza compleja de Butarque en Villaverde Bajo. In: Actas de las IV Jornadas de Patrimonio Arqueológico de la Comunidad de Madrid (2007), CARM, Madrid, pp. 339-343.

Douville, E., Sallé, E., Frank, N., Eisele, M., Pons-Branchu, E., Ayrault, S., 2010. Rapid and accurate U-Th dating of ancient carbonates using inductively coupled plasma-quadrupole mass spectrometry. Chem. Geol. 272, 1-11.

Durcan, J.A., King, G.E., Duller, G.A.T., 2015. DRAC: dose rate and age calculator for trapped charge dating. Quat. Geochronol. 28, 54-61.

Duval, M., 2012. Dose response curve of the ESR signal of Aluminium center in quartz grains extracted from sediment. Anc. TL 30 (2), 41-49.

Duval, M., 2015. Evaluating the accuracy of ESR dose determination of pseudo-Early Pleistocene fossil tooth enamel samples using dose recovery tests. Radiat. Meas. $79(0), 24-32$

Duval, M., Guilarte, V., 2015. ESR dosimetry of optically bleached quartz grains extracted from Plio-quaternary sediment: evaluating some key aspects of the ESR signals associated to the Ti-centers. Radiat. Meas. 78, 28-41.

Duval, M., Grün, R., Falguères, C., Bahain, J.J., Dolo, J.M., 2009. ESR dating of Lower Pleistocene fossil teeth: Limits of the single saturating exponential (SSE) function for the equivalent dose determination. Radiat. Meas. 44, 477-482.

Duval, M., Sancho, C., Calle, M., Guilarte, V., Peña-Monné, J.L., 2015. On the interest of using the multiple centers approach in ESR dating of optically bleached quartz grains: some examples from the Early Pleistocene terraces of the Alcanadre River (Ebro basin, Spain). Quat. Geochronol. 29, 58-69.

Duval, M., Arnold, L.J., Guilarte, V., Demuro, M., Santonja, M., Pérez-González, A., 2017. Electron Spin Resonance dating of optically bleached quartz grains from the Middle Palaeolithic site of Cuesta de la Bajada (Spain) using the multiple centres approach. Quat. Geochronol. 37, 82-96.

Falguères, C., Bahain, JJ. Masaoudi, $H$., 2008. Datation de restes paléontologiques par combinaison des méthodes de la résonance de spin électronique et des séries de l'uranium (méthode ESR/U-Th combinée). In: Moncel, M.H. (Ed.), Le site de Payre: Occupations Humaines dans la vallée du Rhône à la fin du Pléistocène Moyen et au début du Pléistocène supérieur, Mémoires de la Société Préhistorique Française, vol. 46, pp. 110-112.

Foury, Y., Desclaux, E., Daujeard, C., Defleur, A., Moncel, M.H., Raynal, J.P. 2016. Evolution des faunes de rongeurs en moyenne vallée du Rhône (Rive droite, Ardèche, France) au cours du Pléistocène Moyen final et du Pléistocène Supérieur ancien, du MIS6 au MIS4. Quaternaire 27 (1), 55-79.

Giner, J.L., De Vicente, G., Pérez-González, A., Sánchez Cabañero, J.G., Pinilla, L., 1996. Crisis tectónicas cuaternarias en la Cuenca de Madrid. Geogaceta 20 (4), $842-845$.

Goy, J.L., Pérez-González, A., Zazo, C., 1989. Cartografía y Memoria del Cuaternario, Hoja 19-22 (Madrid). In: Mapa Geológico de España 1:50.000 MAGNA. Servicio de Publicaciones del Ministerio de Industria, Madrid, p. 79.

Grün, R., 1994. A cautionary note: use of the water content and depth for cosmic ray dose rate in AGE and DATA programs. Anc. TL 12, 50-51.

Grün, R., 2000. Methods of dose determination using ESR spectra of tooth enamel, Radiat. Meas. 32 (5-6), 767-772.

Grün, R., 2009. The DATA program for the calculation of ESR age estimates on tooth enamel. Quat. Geochronol. 4, 231-232.

Grün, R., Katzenberger-Apel, O., 1994. An alpha irradiator for ESR dating. Anc. TL 12, $35-38$.

Grün, R., Schwarcz, H.P., Chadam, J., 1988. ESR dating of tooth enamel: coupled correction for U-uptake and U-series disequilibrium. Nucl. Tracks. Radiat. Meas. $14,237-241$.

Laplana, C., Herráez, E., Yravedra Saínz de los Terreros, J., Bárez, S., Rubio-Jara, S., Panera, J., Rus, I., Pérez-González, A., 2015. Biocronología de la Terraza Compleja de Butarque del río Manzanares en el Estanque de Tormentas al sur de Madrid (España). Estud. Geol. 71 (1), 1-16.

López-García, J.M., Blain, H.A., Julià, R. Maroto, J., 2014. Environment and climate during MIS7 and their implications for the late Middle Pleistocene hominins: the contribution of Mollet cave, Serinyà, Girona, northeastern Iberian Peninsula. Quat. Int. 337, 4-10.

López-Martínez, N., 1980. Los micromamíferos (Rodentia, Insectivora, Lagomorpha Chiroptera), del sitio de ocupación Achelense de Áridos 1-1 (Arganda, Madrid). In: Santonja, M., López Martínez, N., Pérez-González, A. (Eds.), Ocupaciones Achelenses en el valle del Jarama (Arganda, Madrid), Arqueología y Paleoecología, vol. 1. Diputación Provincial de Madrid, pp. 161-202.

López-Martínez, N., 2009. Time asymmetry in the palaeobiogeographic history of species. Bull. la Soc. Géol. Fr. 180, 45-55.

Manzano, L., Expósito, A., Pérez-González, A., Soto, E., Sesé, C., Yravedra, J., RuizZapata, B., Millán, A., Benéitez, P., Torres, T., Mondéjar, J.A., Zarco, E., Sánchez, H., Citores, A., Ramos, M., Rodríguez, A., 2010. El yacimiento arqueo-paleontológico de E.D.A.R.CULEBRO 1 (Estación Depuradora de Aguas Residuales de la cuenca Baja del Arroyo Culebro). In: Ministerio de Medio Ambiente. Confederación Hidrográfica del Tajo. Actas de las V Jornadas de Patrimonio Arqueológico en la Comunidad de Madrid celebradas en el Museo Arqueológico Regional de la Comunidad de Madrid del 12-14 noviembre de 2008. Alcalá de Henares, Madrid, pp. 203-214.

Maroto, J., Julià, R., López-García, J.M., Blain, H.A., 2012. Chronological and 
environmental context of the middle Pleistocene human tooth of mollet cave (Serinyà, NE Iberian Peninsula). J. Hum. Evol. 62, 655-663.

Moreno, D., Falguères, C., Pérez-González, A., Duval, M., Voinchet, P., BenitoCalvo, A., Ortega, A.I., Bahain, J.J., Sala, R., Carbonell, E., Bermúdez de Castro, J.M., Arsuaga, J.L., 2012. ESR chronology of alluvial deposits in the Arlanzón valley (Atapuerca, Spain): contemporaneity with Atapuerca Gran Dolina site. Quat. Geochronol. 10, 418-423.

Panera, J., 2009. La ocupación del medio fluvial en el Paleolítico antiguo. Caracterización geoarqueológica de depósitos pleistocenos del valle del río Jarama (Madrid) y estudio tecnoeconómico de la industria lítica. Tesis Doctoral. Departamento de Prehistoria y Arqueología. Facultad de Geografía e Historia. Universidad Nacional de Educación a Distancia. Inédita, 705 pp.

Panera, J., Rubio-Jara, S., 2002. Bifaces y elefantes. La investigación del Paleolítico Inferior en Madrid. In: Zona Arqueológica, vol. 1, p. 510.

Panera, J., Pérez-González, A., Rubio-Jara, S., Sesé, C., 2005. El yacimiento paleolítico de HAT en el valle del Jarama: una aportación de Cuaternario de la cuenca de Madrid al debate sobre el inicio del Paleolítico medio. In: Santonja, M., PérezGonzález, A., Machado, M.J. (Eds.), Geoarqueología y Patrimonio en la Península Ibérica y el entorno Mediterráneo. ADEMA, pp. 251-260.

Panera, J., Torres, T., Pérez-González, A., Ortiz, J.E., Rubio-Jara, S., Uribelarrea del Val, D., 2011. Geocronología de la Terraza Compleja de Arganda en el valle del río del Jarama (Madrid, España). Estud. Geol. 67 (2), 495-504.

Panera, J., Rubio-Jara, S., Yravedra, J., Blain, H.A., Sesé, C., Pérez-González, A., 2014. Manzanares valley (Madrid, Spain): a good country for Proboscideans and Neanderthals. Quat. Int. 326-327, 329-343.

Pérez-González, A., 1971. Estudio de los procesos de hundimiento en el valle del río Jarama y sus terrazas (notas preliminar). Estud. Geol. 27 (4), 317-324.

Pérez-González, A., 1980. El marco geográfico, geológico y geomorfológico de los yacimientos de Áridos en la Cuenca del Tajo. In: Santonja, M., López, N., PérezGonzález, A. (Eds.), Ocupaciones achelenses en el valle del Jarama (Arganda, Madrid), Arqueología y Paleontología, vol. I. Diputación Provincial de Madrid, pp. $15-28$.

Pérez-González, A., 1994. Depresión del Tajo. In: Gutiérrez Elorza, M. (Ed.), Geomorfología de España. Ed. Rueda, Madrid, pp. 389-436.

Pérez-González, A., Uribelarrea, D., 2002. Geología del cuaternario en los valles fluviales del Jarama y Manzanares en las proximidades de Madrid. Zona Arqueol. 1, 302-317.

Pérez-González, A., Rubio-Jara, S., Panera, J., Uribelarrea, D., 2008. Geocronología de la sucesión arqueoestratigráfica de Los Estragales en la Terraza Compleja de Butarque (Valle del río Manzanares, Madrid). Geogaceta 45, 39-42.

Pérez-González, A. Gallardo-Millán, J.L. Uribelarrea del Val, D. Panera, J., RubioJara, S., 2013. La inversión Matuyama-Brunhes en la secuencia de terrazas del río Jarama entre Velilla de San Antonio y Altos de la Mejorada, al SE de Madrid (España). Estud. Geol. 69 (1), 35-46.

Prado, C. de, 1864. Descripción física y geográfica de la Provincia de Madrid, $2^{\mathrm{a}}$ ed. Junta General de Estadística, Madrid, 1975. (Colegio de Ingenieros de Caminos, Canales y Puertos, Madrid).

Prescott, J.R., Hutton, J.T., 1994. Cosmic ray contributions to dose rates for luminescence and ESR dating: large depths and long-term time variations. Radiat. Meas. 23, 497-500.

Rubio-Jara, S., 2011. El paleolítico en el valle del río Manzanares (Madrid). Caracterización geoarqueológica de depósitos pleistocenos y estudio tecnoeconómico de la industria lítica (Unpublished PhD thesis). Universidad Nacional de Educación a distancia (UNED).

Rubio-Jara, S., Panera, J., Santonja, M., Pérez-González, A., 2002. Revisión crítica y síntesis del Paleolítico de los valles del Manzanares y Jarama. In: Panera, J., Rubio-Jara, S. (Eds.), Bifaces y elefantes. La investigación del Paleolítico inferior en Madrid, Zona Arqueológica, vol. 1. Museo Arqueológico Regional, Alcalá de Henares, Spain, pp. 338-355.

Rubio-Jara, S., Panera, J., Rodríguez-de-Tembleque, J., Santonja, M., PérezGonzález, A., 2016. Large flake Acheulean in the middle of Tagus basin (Spain): middle stretch of the river Tagus valley and lower stretches of the rivers Jarama and Manzanares valleys. Quat. Int. 411, 349-366.

Ruíz-Zapata, B., Pérez-González, A., Panera, J., Dorado, M., Valdeolmillos, A., Gómez, C., Gil García, M.J., 2006. Middle Pleistocene vegetation in the valley of Jarama river (Casa de la Peña site, Arganda del Rey, Madrid, Spain). In: 7th European Palaeobotany-palynology Conference. Prague, 2006.

Santonja, M., López, N., Pérez-González, A. (Eds.), 1980. Ocupaciones achelenses en el valle del Jarama. Arqueología y Paleontología, vol. 1. Diputación Provincial de Madrid, Madrid.

Sesé, C., Soto, E., 2000. Vertebrados del Pleistoceno de Madrid. In: Morales, J. (Ed.),
Patrimonio Paleontológico de la comunidad de Madrid, Arqueología, Paleontología y Etnografía, vol. 6. Comunidad de Madrid, Madrid, pp. 216-243.

Sesé, C., López-Martínez, N., 2013. Nuevos datos paleontológicos del Pleistoceno en el Valle del Manzanares (Madrid, España): Los micromamíferos del yacimiento del Arenero de Arriaga. Estud. Geol. 69 (2), 271-282.

Sesé, C., Rubio-Jara, S., Panera, J., Pérez-González, A., 2011a. Micromamíferos de Pleistoceno Superior del yacimiento de PRERESA en el valle del Manzanares y su contribución a la reconstrucción paleoambiental de la cuenca de Madrid durante el Pleistoceno. Estud. Geol. 67 (2), 471-494.

Sesé, C., Rubio-Jara, S., Panera, J., Pérez-González, A., 2011b. Micromamíferos del Pleistoceno Medio y Superior en el valle del Jarama: yacimientos de Valdocarros y HAT (Madrid, España). Estud. Geol. 67 (1), 131-151.

Shao, Q., Bahain, J.J., Falguères, C., Peretto, C., Arzarello, M., Minelli, A., Hohenstein, U.T., Dolo, J.M., Garcia, T., Frank, N., Douville, E., 2011. New ESR/Useries data for the early middle Pleistocene site of Isernia la Pineta, Italy. Radiat. Meas. 46, 847-852.

Shao, Q., Bahain, J.J., Falguères, C., Dolo, J.M., 2012. A new U-uptake model for combined ESR/U-series dating of tooth enamel. Quat. Geochronol. 10, 406-411.

Shao, Q., Bahain, J.J., Dolo, J.M., Falguères, C., 2014. Monte Carlo approach to calculate US-ESR age and age uncertainty for tooth enamel. Quat. Geochronol. 22, 99-106.

Shao, Q., Chadam, J., Grün, R., Falguères, C., Dolo, J.M., Bahain, J.J., 2015. The mathematical basis for the US-ESR dating method. Quat. Geochronol. 30, 1-8.

Silva, P.G., 2003. El Cuaternario del valle inferior del Manzanares (Cuenca de Madrid, España). Estud. Geol. 59, 107-131.

Silva, P., Goy, J.L., Zazo, C., 1988. Neotectónica del sector centro-meridional de la cuenca de Madrid. Estud. Geol. 44, 415-427.

Silva, P.G., López-Recio, M., González Hernández, F.M., Tapias, F., Alarcón, A. Cuartero, F., Expósito, A., Lázaro, I., Manzano, I., Martín, D., Morín, J., Yravedra, J. 2008. Datos geoarqueológicos de la terraza compleja del Manzanares entre el sector del 12 de Octubre y la desembocadura del arroyo Butarque (Villaverde, Madrid). Cuaternario Geomorfol. 22, 47-70.

Silva, P.G., Tapias, F., López-Recio, M., Carrasco, P., Morín, J., Roquero, E., Rus, I., 2011. Análisis estratigráfico del arenero de Arriaga (Terraza compleja del Manzanares, Madrid). In: Resúmenes XIII Reunión Nacional de Cuaternario. Andorra 2011.

Silva, P.G., López-Recio, M., Cuartero, F., Baena, J., Tapias, F., Manzano, I., Martín, D. Morín. J., Roquero, E., 2012. Contexto geomorfológico y principales rasgos tecnológicos de nuevos yacimientos del Pleistoceno Medio y Superior en el Valle Inferior del Manzanares (Madrid, España). Estud. Geol. 68, 58-89.

Silva, P.G., Roquero, E., López-Recio, M., Huerta, P., Martínez-Graña, A.M., 2016. Chronology of fluvial terrace sequences for large Atlantic rivers in the Iberian Peninsula (Upper Tagus and Duero drainage basins, Central Spain). Quat. Sci. Rev. 166, 188-203.

Sutton, S.R., Zimmerman, D.W., 1978. Thermoluminiscence dating: radioactivity in quartz. Archaeometry 20 (1), 67-69.

Toyoda, S., Falguères, C., 2003. The method to represent the ESR signal intensity of the aluminium hole center in quartz for the purpose of dating. Adv. ESR Appl. 20, $7-10$.

Toyoda, S., Voinchet, P., Falguères, C., Dolo, J.M., Laurent, M., 2000. Bleaching of ESR signals by the sunlight: a laboratory experiment for establishing the ESR dating of sediments. Appl. Radiat. Isotopes 52 (5), 1357-1362.

Voinchet, P., Falguères, C., Laurent, M., Toyoda, S., Bahain, J.J., Dolo, J.M., 2003. Artificial optical bleaching of the aluminium center in quartz implications to ESR dating of sediments. Quat. Sci. Rev. 22, 1335-1338.

Voinchet, P., Falguères, C., Tissoux, H., Bahain, J.J., Despriée, J., Pirouelle, F., 2007. ESR dating of fluvial quartz: estimate of the minimal distance transport required for getting a maximum optical bleaching. Quat. Geochronol. 2, 363-366.

Woda, C., Wagner, G.A., 2007. Non-monotonic dose dependence of the Ge- and TiCenters in quartz. Radiat. Meas. 42 (9), 1441-1452.

Wolf, D., Seim, A., Díaz del Olmo, F., Faust, D., 2013. Late Quaternary fluvial dynamics of the Jarama river in central Spain. Quat. Int. 302, 20-41.

Yokoyama, Y., Falguères, C., Quaegebeur, J.P., 1985. ESR dating of quartz from quaternary sediments: first attemps. Nucl. Tracks 10 (4-6), 921-928.

Yravedra, J., Domínguez-Rodrigo, M., 2008. The shaft-based methodological approach to the quantification of long limb bones and its relevance to understanding hominid subsistence in the Pleistocene: application to four Palaeolithic sites. J. Quat. Sci. 24 (1), 85-96.

Yravedra, J., Rubio-Jara, S., Panera, J., Uribelarrea, D., Pérez-González, A., 2012. Elephants and subsistence. Evidence of the human exploitation of extremely large mammal bones from the Middle Palaeolithic site of PRERESA (Madrid, Spain). J. Archaeol. Sci. 39, 1063-1071. 